SFB 649 Discussion Paper 2017-018

\title{
Social Security Contributions and the Business Cycle
}

\author{
Anna Almosova* \\ Michael C. Burda* \\ Simon Voigts*
}

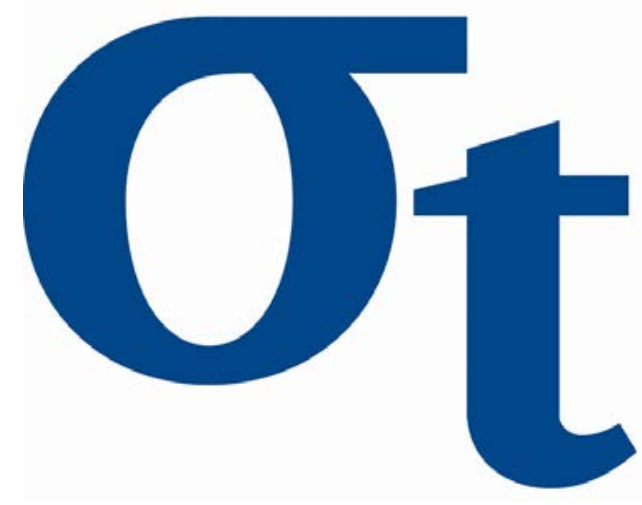

9

$\checkmark$

6

m

U

* Humboldt-Universität zu Berlin, Germany

This research was supported by the Deutsche Forschungsgemeinschaft through the SFB 649 "Economic Risk".

http://sfb649. wiwi. hu-berlin.de ISSN 1860-5664 
June 2017

\title{
Social Security Contributions and the Business Cycle
}

\author{
Anna Almosova \\ Humboldt Universität zu Berlin and CRC 649 \\ Michael C. Burda \\ Humboldt Universität zu Berlin, CEPR, IZA and CRC 649 \\ Simon Voigts \\ Humboldt Universität zu Berlin and CRC 649
}

\begin{abstract}
This paper examines magnitudes and business cycle dynamics of social security contributions (SSC). In most OECD countries studied, we document a negative covariation of payroll tax burdens with GDP and GDP growth at business cycle and lower frequencies. We assess the overall magnitude of the distortion following Barro and Redlick (2011). For most countries, average marginal SSC tax rates exceed average rates, but the latter tracks the former tightly. Changes in average payroll tax burdens are mostly accounted for by changes in tax schedules rather than shifts in the earnings distribution over time. For many countries, SSC rates behave like estimated values of the "labor wedge" (Chari et al. 2007, Brinca et al., 2016).
\end{abstract}

JEL Codes: E24, E32, J32, H55

Keywords: business cycle, payroll tax, social security contributions, labor wedge

This paper has benefited from the research assistance of Thomas Dengler, Tobias König and Judith Sahling and from the useful comments of Pedro Brinca, Thiess Büttner, Peter Egger, Rick van der Ploeg, participants at the 2016 CES-Ifo Area Meeting in Public Economics and the DFG SPP 1764 Third Internal meeting. The support of the Collaborative Research Center 649 and Priority Programme 1764 of the German Science Foundation is gratefully acknowledged. The data used and the series created in this paper can be accessed at https://www.wiwi.hu-berlin.de/de/professuren/vwl/wtm2/mitarbeiter/burda/ssc_schedules_data.zip 


\section{Introduction}

Throughout the developed world, social insurance programs - including unemployment benefits, work disability insurance programs, health insurance, old-age pensions as well as other programs aimed at social inclusion - redistribute a significant share of a country's national income. This redistribution is financed to a large part by social security contributions (SSC). Representing more than half of the total tax on labor income in OECD member countries, SSC are little different from dedicated payroll taxes, and dominate the difference between employers' costs of labor and the direct monetary benefit received by workers. In 2013, total SSC in OECD countries amounted to about $\$ 4.4$ trillion, or about 9 percent of GDP; in some economies, social security contributions represented as much as 19 percent of a country's GDP, or 40 percent of total labor compensation. Even if workers perceive these contributions as paying for realized or potential benefits in social security programs, SSC or payroll taxes remain likely to represent a significant distortion in the worker-firm relationship. ${ }^{1}$

This paper investigates the cyclical behavior of social security contributions in 25 OECD countries over the period 1960-2015. To our knowledge, the origins and the dynamics of SSC over the business cycle have yet to be systematically studied. ${ }^{2}$ We document that for a majority of countries and time intervals, average SSC rates (defined as the total SSC divided by total gross labor compensation) vary counter-cyclically with respect to growth and output, especially at business cycle frequencies, declining in booms and rising in recessions. This feature is not shared by all countries, especially those in which the value-added tax and other sources of general revenue cross-subsidize social security budgets. Because payroll taxation

\footnotetext{
${ }^{1}$ Gruber (1997) argues that labor supply may be higher despite lower take-home pay and offset the distortion if workers associate payroll taxes with additional forms of compensation, i.e. health care, pension, unemployment and disability, as well as other forms of insurance not offered in the market; yet there is no reason to expect this offset to be perfect.

${ }^{2}$ Burda and Weder (2016) report similar regularities in a smaller group of countries; see also Gali et al. (2007) and Vegh and Velutin (2013).
} 
represents the average burden of a worker-job match in a frictional labor market, this cyclicality has potentially important implications for labor market dynamics. ${ }^{3}$

There are two prominent sources of cyclical variation in aggregate payroll taxation. First, holding tax schedules constant, shifts in the distribution of gross labor earnings change the SSC burden relative to the wage bill if, for example, the tax schedule consists of different piecewise linear brackets. Second, "Bismarckian” balanced budget principles applied to social funds may require adjustment of the tax schedule to meet revenue shortfalls in recessions and trim surpluses in booms. In order to quantify the relative importance of these two alternatives, we propose an accounting framework for decomposing movements in average SSC rates. We find that the lion's share of observed changes in annual average contributions rates is directly attributable to adjustments in statutory tax schedules. Following Barro and Redlick (2011) we show that these average tax burdens co-vary with effective marginal tax rates, with the latter exceeding the former in almost all cases. In many countries, our estimates are also correlated with estimates of the "labor wedge" or labor market distortion described by Chari et al (2007) and Brinca et al. (2016) in their business cycle accounting framework.

The rest of the paper is organized as follows. Section 2 presents the data and long-run observations. Section 3 discusses long-term characteristics of social security contributions in our sample. Section 4 presents empirical findings on cyclical properties of contribution rates and evaluates the sources of this behavior at cyclical and lower frequencies. Section 5 examines the behavior of the SSC tax burden in the context of the business cycle accounting framework of Chari, et al. (2007). Section 6 concludes.

\footnotetext{
${ }^{3}$ As discussed below in more detail, the possibility that this distortion may fluctuate over time may offer an account of cyclical variation of output and employment at business cycle frequencies (see Chari, et al. 2007). Burda and Weder (2016) show that a countercyclical payroll tax burden driven by a balanced budget constraint can help explain the Hall-Shimer anomaly. Voigts (2015) shows that the nominal incidence of social security contributions for households and firms in model with nominal rigidities can overturn tax liability equivalence and significantly affect the nature of business cycle fluctuations.
} 


\section{Data description and trends}

\subsection{Average contribution (payroll tax) rates}

We construct our standard measure of average social security contributions paid by firms and workers expressed as a fraction of total wage costs (henceforth: SSC rate) using two time series published by the OECD. ${ }^{4}$ These annual data from 25 advanced countries range from 1960 to 2015. The first times series, "Social Security Contributions Received by General Government," includes contributions to pension funds, disability and health insurance, as well as unemployment insurance and related programs. ${ }^{5}$ The second series is "Compensation of Employees", defined as the sum of wages, salaries and social insurance contributions paid by employers directly or on behalf of their employees.

Table 1 displays the size of SSC relative both to GDP and overall labor compensation in 2015 and shows that they are significant in OECD economies. In most European countries, social contribution comprise $10-20 \%$ of GDP and as much as $30 \%$ and more of total labor compensation, but less than $5 \%$ of GDP or $10 \%$ of total labor compensation in the US, Canada and New Zealand. ${ }^{6}$ Since we are interested in the size of labor market distortions, we focus only on the sum of employer and employee contributions, and exclude personal income taxes and indirect taxation (e.g. value-added taxes), that affect real household income deriving from market activities in general. The first and second columns summarize the size of the labor

\footnotetext{
${ }^{4}$ OECD Economic Outlook 95 (2015).

${ }^{5}$ Households can make social security payments to the government or a governmental or non-government agency, or even private social security funds, with a breakdown which varies across countries. Transfers to non-government funds are not included in our measure. For example, in the Netherlands, private disability insurance is not included in government social security receipts (See OECD 2007 in Data Sources). We repeated our analysis for several countries using social security payments by households and obtained very similar results.

${ }^{6}$ Because we only analyze contributions into social security systems and not payments that employees receive from social security funds, our measures in Table 1 understate the size of the social security system (in Canada or Denmark, for example).
} 
wedge and the magnitude of the distortion, while the significance of the social security system in a particular country is captured in the third column.

\section{<Table 1 here $>$}

Let $\tau^{A}{ }_{t}$ denote the average SSC rate in year $t$, given by the ratio of total social security contributions to the wage bill - the sum of all wages, salaries and non-wage payments made by employers on behalf of employees:

$$
\tau_{t}^{A}=S S C_{t} / \text { wage bill }
$$

While the OECD computes similar indicators, ours aggregates over all households and includes both employer and employee SSC payments. ${ }^{7}$ Assuming that workers and firms take such payments into account when entering into an employment contract, $\tau^{A}$ may be thought of as the unconditional average SSC rate faced by a worker-employer match and the ex-ante distortionary burden on the value of a firm-worker match. Figure 1 presents $\tau^{A}$ for all countries in our sample and reveals significant heterogeneity across the OECD in level, trend and cyclical behavior.

\section{$<$ Figure 1 here $>$}

\subsection{Marginal payroll tax rates}

The average SSC rates displayed in Figure 1 and in the first column of Table 1 do not necessarily provide a fully accurate measure of the distortionary impact of labor taxes, because they do not represent the true marginal tax burden arising from payroll taxation. To measure this, Barro

\footnotetext{
${ }^{7}$ The OECD constructs "Average rate of employees' social security contributions" and "Average rate of employers' social security contributions" for eight different household types. See: http://stats.oecd.org/Index.aspx?DataSetCode=AWCOMP\# Both OECD indicators are calculated starting from year 2000, while our series begin in 1960 for many countries.
} 
and Sahasalul (1983, 1986) and Barro and Redlick (2011) construct average marginal tax rate series for US workers (see also Joines 1981 and Seater 1982), which represent a weighted central tendency of marginal payroll taxation for individuals over various points of the earnings distribution in the economy. The weights measure the relative importance of a particular individual. ${ }^{8}$ Not having access to individual data, we construct series of average marginal SSC rates using a different procedure with two different OECD data sources.

The first OECD database, “Taxing Wages 2016," covers 32 countries from 1981 to 2015 and provides annual data for each country's SSC tax schedule, including tax brackets and respective rates for non-linear schedules..$^{9}$ Almost all countries in our sample have separate tax schemes for employers and employees; for our purposes, marginal rates for corresponding tax brackets on either side are simply added together, resulting in a consolidated payroll tax schedule for the worker-firm match. ${ }^{10}$ SSC schedules differ considerably across OECD countries in our sample: In 2015, Belgium, Hungary, Greece, Finland, New Zealand and Slovenia had a flat payroll tax schedule, while Iceland, Denmark and Spain use lump-sum payments or fixed minimum contributions for all workers. The remaining countries in the sample have progressive or regressive tax schemes with different marginal SSC rates applied to different levels of earnings. In 2015, 9 of 25 countries covered by our dataset capped social security contributions at some earnings level above which the marginal SSC rates is zero. Countries with a maximum taxable level of income include Austria, Canada, Germany, Greece, Israel, Italy, Netherlands, Slovak Republic and Spain. ${ }^{11}$ Figure 2 displays SSC tax schedules for six representative countries in 2015, with level of labor

\footnotetext{
${ }^{8}$ Barro and Sahasakul (1983) use shares of individual consumption in aggregate consumption as weights, other approach might be income-weighted or population-weighted averages.

${ }^{9}$ Our dataset and detailed descriptions of the social security systems are available on request.

${ }^{10}$ This procedure ignores lump-sum payments and fixed minimum contributions. These payments are independent of the business cycle and, presumably do not distort the labor supply margin. We also ignore the fact that in some countries tax schedules vary depending on the family status. For this reason, some countries (e.g. Norway) were excluded from our dataset. All threshold values for annual earnings are reported an https://www.wiwi.huberlin.de/de/professuren/vwl/wtm2/mitarbeiter/burda/ssc_schedules_data.zip

${ }^{11}$ In the United States, a tax ceiling applies to all social security contributions except those for Medicare, which are currently unlimited. In 2017, this ceiling was $\$ 127,200$.
} 
compensation subject to social security contributions on the horizontal axis, and the corresponding marginal SSC rate applied on the vertical axis. ${ }^{12}$

\section{$<$ Figure 2 here $>$}

The second OECD database used in for constructing the average marginal SSC taxation series is "Distribution of gross earnings of full-time employees."13 This database comprises annual observations of nine wage deciles of the gross earnings distribution of full-time employees in 27 OECD countries for 1975-2010 (in hourly, weekly, monthly or annual rates depending on the country). We apply schedules of statutory contributions to standardized annual earnings at each of the $i^{\text {th }}$ deciles $i \in\{1,2, \ldots 9\}$ of contemporaneous earnings distributions (net of employers' contributions) and arrive at a marginal tax rate $\tau_{i t}$ (i.e. the SSC tax rate applicable to an additional unit of gross compensation at a particular decile). An unweighted average over the nine marginal rates yields the following "average marginal tax rate" $\bar{\tau}_{t}=$ $\frac{1}{9} \sum_{1}^{9} \tau_{i t}$. For a given year and country, observations can be constructed only if data for both the tax schedule and wage distribution are available. For 10 countries in our OECD sample, this requirement is satisfied for 10 years or more. Figure 3 displays the time series of average marginal rates (red dashed lines), as well as average SSC rates described in Section 1 (blue solid lines). In all countries except Canada and Japan, average marginal rates are higher than the average SSC tax burden. The reason is that aggregate consolidated tax schedules are regressive (and/or truncated) in most countries as evident from Figure 2, so low-income workers tend to face the highest marginal rates. The results suggest that average rates payroll tax rates understate the distortionary effect of SSC, despite the regressivity of the schedules for any given worker in most countries.

\footnotetext{
${ }^{12}$ Figure 7 shows the evolution of tax schedules over time for the exemplary cases of France and Germany. ${ }^{13}$ Available under http://www.oecd.org/els/emp/39606921.xls
} 


\section{$<$ Figure 3 here $>$}

The following simple example illustrates how this is possible. A population consists of three families, with gross labor earnings of 20,000, 60,000, and 200,000 respectively. These families face a truncated SSC schedule that levies a uniform $30 \%$ tax on gross income up to 61,000 , but $0 \%$ on income exceeding 61,000 . The average SSC tax rate $\tau^{A}$ is $(0.3 * 20,000+0.3 * 60,000+0.3 * 61,000) /(20,000+60,000+200,000)=15.1 \%$, significantly below the average marginal rate $\bar{\tau}$ of $(0.3+0.3+0) / 3=20 \%$.

Figure 3 shows that in most countries, the average SSC tax rate $\tau^{A}$ moves closely with our measure of marginal SSC rates $\bar{\tau}$, representing an average impact of statutory rates at the margin for nine representative earners. For each country, correlations between the two are presented above the panels of the graph and support this assessment. The average tax rate appears to be a good rough indicator of levels and especially changes in the marginal distortion for the average marginal tax rate, or the tax rate relevant for labor supply decisions.

\subsection{Tracking the origins of changes in average marginal tax rates}

The rich detail on payroll tax schedules available from the OECD allows us to explore sources of variation in $\tau^{A}$ over time. First, the average tax burden can shift if tax schedules are changes. Movements in marginal rates or contribution ceilings can have large effects on aggregate contributions actually paid. Second, the distribution of earnings itself may change, implying higher rates applied to marginal income, or lower rates if marginal income lies above the cutoff threshold income level. This shift need not only involve the first moment of the distribution, because changes in variance or higher moments can also matter for the overall tax burden. Suppose that the economy described in the previous section experiences $10 \%$ earnings 
growth, so one family earns 22,000 , one earns 66,000 , and one earns $220,000 .{ }^{14}$ The average tax rate is now $(0.3 * 22,000+0.3 * 61,000+0.3 * 61,000) /(22,000+66,000+220,000) \approx 14 \%$, while the average marginal rate falls to $(0.3+0+0) / 3=10 \%$.

\section{Trend and cyclical properties of SSC rates}

\subsection{Low frequency movements}

Before considering business cycle frequency properties of our constructed series in Section 3, we examine the medium to long trends in the average social security contributions rate. It is instructive to begin with the case of Germany, the largest EU economy with an extensive social security system financed to a large extent by SSC. Figure 4 shows that, over a half-century, Germany experienced a secular rise in $\tau^{A}$ of almost 15 percentage points, reaching a peak in 1998. This rise has been reversed somewhat since then, especially after 2003-5, the years of the Hartz labor market reforms. The rises in $\tau^{A}$ coincide with periods of economic downturn or structural change (the two oil crises of the 1970s and the German reunification episode).

\section{$<$ Figure 4 here $>$}

The hypothesis that growth downturns are followed by increases in $\tau^{A}$ finds support in many of the countries examined in this study. Figure 5 presents cross-correlograms up to order 10 for the annual data of the countries with sufficient observations for leads and lags of annual growth of GDP $Y$ (approximated as $\Delta \ln Y_{\mathrm{t}}$ ) with $\tau^{A}{ }_{t+i}$ for $\left.i=-10,-9, \ldots 0, \ldots+9,+10\right)$. The most salient finding is a robust statistical significance of negative correlations of current $\Delta \ln Y_{\mathrm{t}}$ with

\footnotetext{
${ }^{14}$ If the cap is not adjusted for inflation, the distinction between real and nominal wage gains is irrelevant.
} 
$\tau^{A}{ }_{t+i}$ for $i>0$ (future payroll tax rates) of the continental European countries Austria, Belgium, France, Italy, Spain, and Sweden as well as their "Bismarckian offshoots" Japan, South Korea and the United States. The correlation of rates with future output, while negative in these countries, is less strong and consistent. In contrast, countries with insurance programs in the tradition of Beveridge (the UK, Canada, Australian, and New Zealand) show little or no covariation. ${ }^{15}$ This raises the general suspicion that the SSC rates are driven by economic conditions. A leading hypothesis is that rising wage bills make more resources available for redistribution purposes, possibly inducing governments to cut payroll tax rates in good times to compensate for low profitability in recessions.

\section{$<$ Figure 5 here $>$}

Policies that reinforce distortions in downturns have potentially severe consequences for allocative efficiency. Daveri and Tabellini (2000) present evidence that labor taxation is a first order cause of high unemployment in OECD economics at low frequencies; SSC are an obvious candidate for a driver of the labor wedge in the sense of Chari et al. $(2007,2016)$ and possibly represent a "smoking gun" linking the labor wedge directly to business cycle dynamics.

\subsection{Cyclical properties of SSC rates}

The findings presented in Figure 4, while relatively unambiguous for some countries, may be confounded by low-frequency trends in the data. During the sample period, growth exhibited a downward trend while the scope of social insurance programs was expanded across the OECD, so strong negative correlations may be spurious due to common, low-frequency trends. In this section, we report results for several detrending procedures and study the association at business-cycle frequencies corresponding to a periodicity of 2-7 years. We also

\footnotetext{
${ }^{15}$ Several economies seem to have undergone regime shifts over the 50 year interval. Burda and Weder (2016) find that over the period 1970-2010, the Netherlands and Sweden appear to have switched from a Bismarck-style regime to a Beveridge one, while the US moved in the opposite direction after the $1980 \mathrm{~s}$.
} 
examine the robustness of correlations over the sample for signs of potential sub-sample instability.

Table 2 provides a first account of these dynamics. The first two columns show the average level of the SSC rate over the two sub-periods, while the third and fourth columns present coefficients of variation over those same sub-periods. For roughly half the countries, average payroll tax burdens have increased, sometimes significantly, as in Germany. The last two columns present correlations of HP-filtered trend deviation of average SSC rates and the natural log of output for the two subsamples as well as the entire period. Over the entire interval, the results roughly confirm the split identified in the previous section between continental European countries with negative correlations (Austria, Belgium, Finland, France, Germany) versus the Beveridge countries (UK, the Scandinavian countries, the US, the Netherlands, Italy). The subperiod correlations suggest regime shifts for the US, Sweden, the Netherlands, Iceland, South Korea and Spain. Of these, only Sweden and the Netherlands moved from a Bismarck to the Beveridge paradigm. The US seems to have moved in the opposite direction.

\section{$<$ Table 2 here $>$}

The HP filter has been criticized for inducing spurious cyclicality (e.g. King and Rebelo, 1993, Cogley and Nason, 1995). To examine the robustness of our findings to detrending method, we compute the correlations using first differences and the band-pass filter (Burnside and Christiano, Fitzgerald, 2003) with lower and upper periodicity bounds of $(2,8)$ and $(3,7)$, returning components with frequencies in the interval $[\pi / 4, \pi]$ and $[2 \pi / 7,2 \pi / 3]$, respectively. The results for the sampling interval 1960-2012 are collected in Table 3. To facilitate comparison between correlations derived under different filtering methods, the last column plots the magnitudes of the four correlation coefficients in each country. 
<Table 3 here $>$

Table 4 repeats the analysis for different filters, but with SSC rates leading or lagging one period. We report dynamic correlations because a reaction of SSC rates to business cycle fluctuations may be delayed, especially if due to adjustments in the tax schedule; policy changes might be subject to decision as well as to data collection lags. In most countries, the lead of average SSC rates is indeed strongly countercyclical, and this finding is robust to the detrending method. For Germany, the UK, Denmark, Finland, Japan, Norway and Canada, dynamic correlations for one period ahead average SSC rates are negative and even stronger than contemporaneous correlations. For the UK, the Czech Republic and Denmark, the contemporaneous correlation is positive (see Table 2), while the correlation between GDP in period $t$ and the average SSC rate in the subsequent period is negative. Italy and Norway appear to have a positive co-movement of average SSC rates and the log of GDP both contemporaneously and with average SSC rate lead one period. In the US, the contemporaneous correlation becomes negative after 1990, as we pointed out in the context of Table 2. Correlation of SSC rate lead and GDP is positive, however, when the entire time period is considered.

\section{$<$ Table 4 here $>$}

We conclude that average SSC rates are counter-cyclical for many, but not all OECD countries. This dynamic pattern of social security contributions implies that the distortionary wedge between labor costs of a firm and the net wage received by a worker worsens in business cycle downturns. The social security system may thus amplify business cycle shocks through the economy. Equally striking are the strong negative correlations of SSC rates with output at lower frequencies than those associated with the business cycle, a finding consistent with Daveri and Tabellini (2000). 


\section{Deconstructing the Mechanism: Reasons for cyclical SSC rates}

Time variation in average SSC employment burdens observed in Figures 1 and 3 can arise from two sources. First, statutory tax schedules are adjusted in response to revenue needs over time, either as changes in a single tax rate in the case of a flat tax schedule, or several tax brackets and corresponding rates in the case of a non-linear schedule. Second, holding tax brackets and cutoffs constant, the distribution of labor earnings can change over time, altering tax revenues in the process. To see how variability in the wage distribution affects the average SSC rate, consider a regressive tax schedule as found in Germany, France or Spain, displayed in Figure 2. An overall increase in gross earnings during an expansion moves a larger fraction of taxable income into brackets with lower tax rates, so the average tax rate declines. Furthermore, if the tax schedule features a cut-off or threshold value of taxable income (as in Germany, Netherlands or Spain), a surge in gross earnings implies that a higher fraction of total gross compensation may exceed this threshold and be exempt at the margin. Similarly, a decline in earnings during a downturn means that a larger fraction of gross labor income falls into lower tax brackets with higher marginal tax rates (or lies below a cut-off value), so the average SSC rate is higher. Since tax schedules are not strictly linear for most countries in our sample, variability in the wage distribution is a potentially important driver for the observed variability in average SSC rates.

In this section we assess the relative importance of the statutory tax rates versus income changes as sources of variation in SSC. To this end, we decompose changes in average SSC rates faced by nine representative earners into two components: one the first captures changes solely due to adjustments in tax schedules, while the other is due to shifts in earnings distributions. We begin by constructing series of social security contributions by combining our dataset on tax schedules with data on gross labor earnings distributions. Again, we consider nine representative earners (indexed by $i$ ) associated with the nine deciles of the gross earnings 
distribution as reported by the OECD. In each period $t$, social security contributions paid by worker $i$ with gross labor earnings $W_{i, t}$ are given by

$$
S S C_{i, t}=\sum_{k=1}^{K} I\left(W_{i, t}-B_{k, t}>0\right) \tau_{k, t}\left[\min \left(B_{k, t}, W_{i, t}\right)-B_{k-1, t}\right],
$$

where $k \in 1, \ldots, K$ indexes tax brackets of the SSC schedule $\left\{\tau_{k, t}, B_{k, t}\right\}$ stipulating tax rate $\tau_{k, t}$ applied to labor income greater than $B_{k-1, t}$ but less than $B_{k, t}$, where $B_{0, t}=0$ and $I($.$) is the indicator$ function. ${ }^{16}$ For this earner, $\tau^{A}{ }_{i, t}=S S C_{\mathrm{i}, t} / W_{\mathrm{i}, \mathrm{t}}$. We define the economy-wide synthetic indicator $\tau^{A^{*}}$ of average payroll taxation over the nine deciles as the unweighted average of nine average rates:

$$
\tau_{t}^{A *}=\frac{1}{9} \sum_{i=1}^{9} \tau_{i, t}^{A}
$$

In contrast to the average $\mathrm{SSC}$ rate $\tau^{A}$ computed in Section $2, \tau^{A^{*}}$ is a synthetic average tax burden constructed from tax schedule and gross earnings data. Differences are due to aggregation of wage distribution information into deciles, and because the uppermost decile is missing.

As the two measures track each other fairly well, the decomposition allows us to track year-to-year changes $\Delta \tau_{t}^{A *}$ as the sum of two components. The first, $\Delta \tau_{t}^{S}$ (S for "statutory"), is due to changes in the tax code between period $t-1$ and $t$ applied to the distribution of earnings in period $t-1$. Formally,

$$
\begin{aligned}
\Delta \tau_{t}^{S}= & \frac{1}{9} \sum_{i=1}^{9} \frac{\Delta S S C_{i, t}}{W_{i, t-1}}=\frac{1}{9} \sum_{i=1}^{9}\left\{\sum_{k=1}^{K} \frac{I\left(W_{i, t-1}-B_{k, t}>0\right) \tau_{k, t}\left[\min \left(B_{k, t}, W_{i, t-1}\right)-B_{k-1, t}\right]}{W_{i, t-1}}\right. \\
& -\sum_{k=1}^{K} \frac{I\left(W_{i, t-1}-B_{k, t-1}>0\right) \tau_{k, t-1}\left[\min \left(B_{k, t-1}, W_{i, t-1}\right)-B_{k-1, t-1}\right]}{W_{i, t-1}}
\end{aligned}
$$

\footnotetext{
${ }^{16} \mathrm{We}$ ignore lump-sum payments to social insurance funds, which are relatively rare; Switzerland is a prominent example.
} 
The second component $\Delta \tau_{t}^{D}$ ( $D$ for "distribution") is a residual, comprised of changes in the earnings distribution at the tax structure in period $t-1$, plus second order effects due to possible interaction of tax schedules and earnings changes: $\Delta \tau_{t}^{D} \equiv \Delta \tau_{t}^{A *}-\Delta \tau_{t}^{S}$.

Plots of implied sources of changes in $\Delta \tau^{A^{*}}$ are presented for the 10 countries in Figure 6. Evidently, policy adjustments in tax schedules are the dominant source of year-to-year changes in average SSC rates. For France, the wage component appears to offset the statutory component before 1990. After this point, the SSC tax follows the policy component closely. Similar patterns can be observed in the other countries. Table 5 additionally presents average absolute changes of actual average SSC rates, the component due to policy changes and a residual due to changes in the structure of earnings. The results show that average rates of changes in SSC rates are close to changes in policy components. In Austria, France and the UK, changes in policy component are even stronger than the total change. The change due to the movements in the wage distribution and residual counteract the changes due to policy and mitigate the total change. Judging from the relative magnitudes, we conclude that policy component is a primary source for the total change in average SSC rates. ${ }^{17}$

\section{$<$ Figure 6 here $>$}

\section{$<$ Table 5 here $>$}

\section{Interpreting SSC rates as a labor wedge}

We have demonstrated a strong correlation of our SSC tax burden measure with output, both at business cycle and lower frequencies. Naturally, correlation is not causation, and a number of third factors might lie behind the macroeconomic co-movements. Yet any plausible

\footnotetext{
${ }^{17}$ This claim is corroborated by unreported individual regressions of changes in overall average $\mathrm{SSC}$ rates $\left(\Delta \tau_{\mathrm{A}}\right)$ on $\Delta \tau_{\mathrm{S}}$ and $\Delta \tau_{\mathrm{D}}$ respectively, in the spirit of columns (3) and (5) in Table 5. $\mathrm{R}^{2}$ 's for statutory rate changes are lower, sometimes significantly so, but with the exception of Austria always exceed the fraction of variance that can be accounted for by shifts in the earnings distribution.
} 
explanation for a rise of average SSC rates displayed in Figure 1 during economic downturns must appeal to some combination of 1) decline in employment and/or the wage bill, 2) a rise in productivity and GDP relative to the wage bill, and 3) a reaction of the tax structure to compensate for the lost revenue. The role of the last channel is substantiated by our analysis of average statutory marginal tax rates, which also move upwards in recessions.

Crucial to any causal mechanism, however, is the role of labor costs in explaining economic downturns. We conclude our analysis by comparing the properties of SSC rates with Chari et al.'s (2007) measure of the labor wedge in their "business cycle accounting" framework for countries with sufficiently long series. This decomposition attributes components of deviations of realized GDP to four distortions from a path implied by some theoretical RamseyCass-Koopmans growth path. Chari et al. (2007) show that several broad classes of macroeconomic models can be mapped into four types of deviations from a putative steady state. While the method itself is not uncontroversial, it would seem that our measure of SSC rates should correspond, conceptually, to the labor market distortion described by Chari et al. (2007) and Brinca et al. (2016) as the "labor wedge".

Table 6 presents correlations of our average SSC rates and the labor wedge, which we compute using the now-standard business cycle accounting procedure (Chari, et al. 2007) and represents the discrepancy between marginal product of labor and a marginal rate of substitution of consumption for leisure. The first column shown correlation coefficients between average SSC rates and labor wedges computed with our data directly from first order conditions. For most of the countries examined, the correlation is positive and significant. This is especially true for the countries with countercyclical SSC rates: Germany, UK, Greece, Finland, Japan, Belgium, Ireland, Poland, Canada, South Korea, Iceland and Spain. Countries with procyclical SSC rates have low or negative correlation between average SSC rates and labor wedge: USA, 
Hungary, Norway, and Czech Republic ${ }^{18}$. The second column presents correlation coefficients between our measure of average SSC rates and labor wedges taken from Brinca et al. (2016). A different method for computing the labor wedge as well as a different time span result in slightly different numbers. However, for UK, Finland, Belgium, South Korea, Iceland and Spain we still get a high positive correlation. The evidence strongly suggests that SSC taxes embody an important labor market distortion of the type readily described by Chari et al. (2007) and Brinca et al. (2016).

\section{$<$ Table 6 here $>$}

\section{Conclusion}

To the extent that the business accounting framework has economic content, it should be possible to identify empirical counterparts to the distortions or "wedges" which prevent the representative agent from achieving the idealized path associated with the neoclassical growth model. We have identified social security contributions as one highly salient and measurable distortion in the labor market that qualify as the empirical counterpart of the labor market distortion or "wedge." Social security contributions rates co-move negatively with the business cycle in the majority of economies, especially in those in which social insurance is financed along the lines of Bismarckian principles. In good times when social insurance funds are flush with cash, contribution rates are cut; in bad times, rates are increased. Models of business cycle fluctuations that attribute a significant role to endogenous propagation arising from labor market distortions should thus directly model dynamics of the payroll tax as an important, if not central component of that mechanism. Models capable of explaining low frequency

\footnotetext{
${ }^{18}$ We also computed a simplified version of the "government consumption wedge" and "efficiency wedge" (Chari, et al. 2007). Average SSC rates are negatively correlated with the efficiency wedge and positively correlated with the government spending wedge. Similar correlations for Sweden are reported by Brinca (2013). Gali et al. (2007) and Hall (1997) discuss the countercyclical nature of labor wedge, while Mulligan $(1998,2002)$ presents evidence that federal labor tax and labor wedge are highly correlated at low frequencies.
} 
fluctuations of unemployment are in short supply and the payroll tax mechanism appears to be a promising avenue for progress in this area, especially in Europe. 


\section{References}

Barro, R.J. and Redlick, C.J., 2011. Macroeconomic effects from government purchases and taxes. The Quarterly Journal of Economics, 126(1), pp.51-102.

Barro, R.J. and Sahasakul, C., 1983. Measuring the average marginal tax rate from the individual income tax.

Barro, R.J. and Sahasakul, C., 1986. Average marginal tax rates from social security and the individual income tax. Journal of Business, University of Chicago Press, vol. 59(4), 555-66.

Beveridge, W.H., 1944. The government's employment policy. The Economic Journal, 54(214), pp.161-176.

Brinca, P., 2013. Monetary business cycle accounting for Sweden. The BE Journal of Macroeconomics, 13(1), pp.1085-1119.

Brinca, P., Chari, V.V., Kehoe, P.J. and McGrattan, E., 2016. Accounting for business cycles. Handbook of Macroeconomics, 2, pp.1013-1063.

Burda, M.C. and Weder, M., 2015. Payroll taxes, social insurance, and business cycles. Journal of the European Economic Association.

Chari, V.V., Kehoe, P.J. and McGrattan, E.R., 2007. Business cycle accounting. Econometrica, 75(3), pp.781-836.

Christiano, L.J. and Fitzgerald, T.J., 2003. The band pass filter. International Economic Review, 44(2), pp.435-465.

Cogley, T. and Nason, J.M., 1995. Effects of the Hodrick-Prescott filter on trend and difference stationary time series Implications for business cycle research. Journal of Economic Dynamics and Control, 19(1), pp.253-278.

Gali, J., Gertler, M. and Lopez-Salido, J.D., 2007. Markups, gaps, and the welfare costs of business fluctuations. The Review of Economics and Statistics, 89(1), pp.44-59.

Gruber, J., 1997, "The consumption smoothing benefits of unemployment insurance," American Economic Review, March, 192-205.

Joines, D., 1981. Estimates of effective marginal tax rates on factor incomes. Journal of Business: 191-226.

Keynes, J. M., 1942: The collected writings of John Maynard Keynes Volume 27. Edited by Donald Moggridge. Macmillan, Cambridge University Press, 217-8.

King, R.G. and Rebelo, S.T., 1993. Low frequency filtering and real business cycles. Journal of Economic Dynamics and Control, 17(1-2), pp.207-231.

Mulligan, C.B., 1998. Substitution over time: another look at life-cycle labor supply. NBER Macroeconomics Annual, 13, pp.75-134.

Mulligan, C.B., 2002. A century of labor-leisure distortions. NBER Working Paper w8774. 
Ravn, M.O. and Uhlig, H., 2002. On adjusting the Hodrick-Prescott filter for the frequency of observations. Review of Economics and Statistics, 84(2), pp.371-376.

Seater, J.J., 1982. Marginal federal personal and corporate income tax rates in the US, 19091975. Journal of Monetary Economics, 10(3), pp.361-381.

Voigts, S., 2015. The distribution of payroll taxes between firms and workers and the business cycle. CRC 649 Discussion Paper, Humboldt University. 


\section{Appendix: Data Sources}

OECD: "Economic Outlook", Volume 2015 issue 2, source; http://www.oecdilibrary.org/economics/oecd-economic-outlook-volume-2015-issue-2_eco_outlook-v2015-2en

OECD: “Taxing wages 2016”, source: http://www.oecd.org/tax/tax-policy/taxdatabase.htm\#ssc

OECD: "Sickness and Disability Schemes in the Netherlands", Country memo as a background paper for the OECD Disability Review. November 2007, source: http://www.oecd.org/social/soc/41429917.pdf

OECD: "LFS - Minimum wages and gross earning of full employees". source: http://www.oecd.org/employment/emp/lfs-minimumwagesandgrossearningsoffulltimeemployees.htm

Eurostat: Taxation trends in the European Union Data for the EU Member States, Iceland and Norway, Statistical book, Eurostat 2014, source:

http://ec.europa.eu/taxation_customs/resources/documents/taxation/gen_info/economic analy $\underline{\text { sis/tax_structures/2014/report.pdf }}$

European Commission 201:VAT Rates Applied in the Member States of the European Union, 2015, source:

http://ec.europa.eu/taxation_customs/resources/documents/taxation/vat/how_vat_works/rates/ vat_rates_en.pdf 


\section{Tables and Figures}

Figure 1: Average tax rates in OECD countries, 1960*-2015
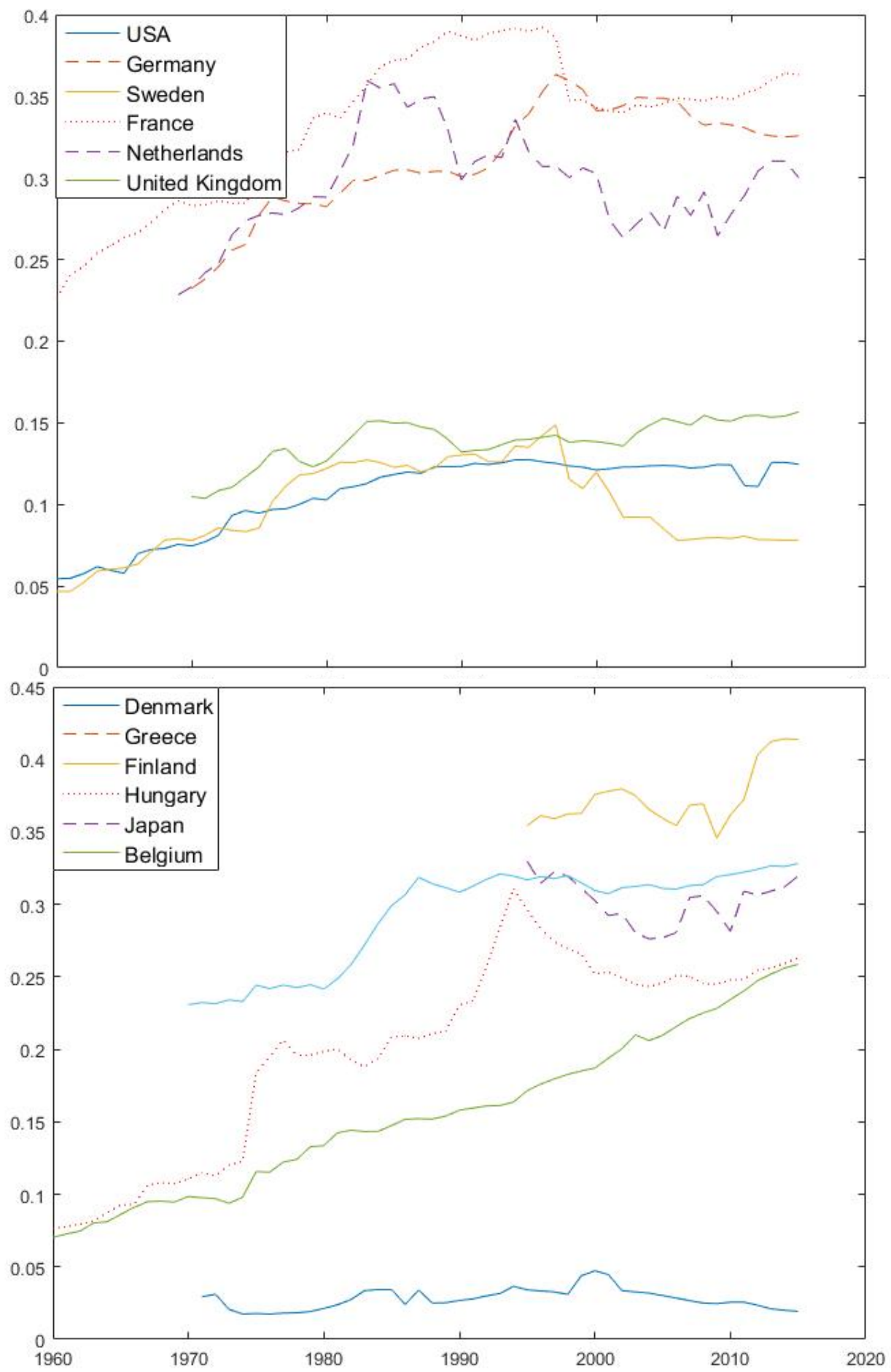

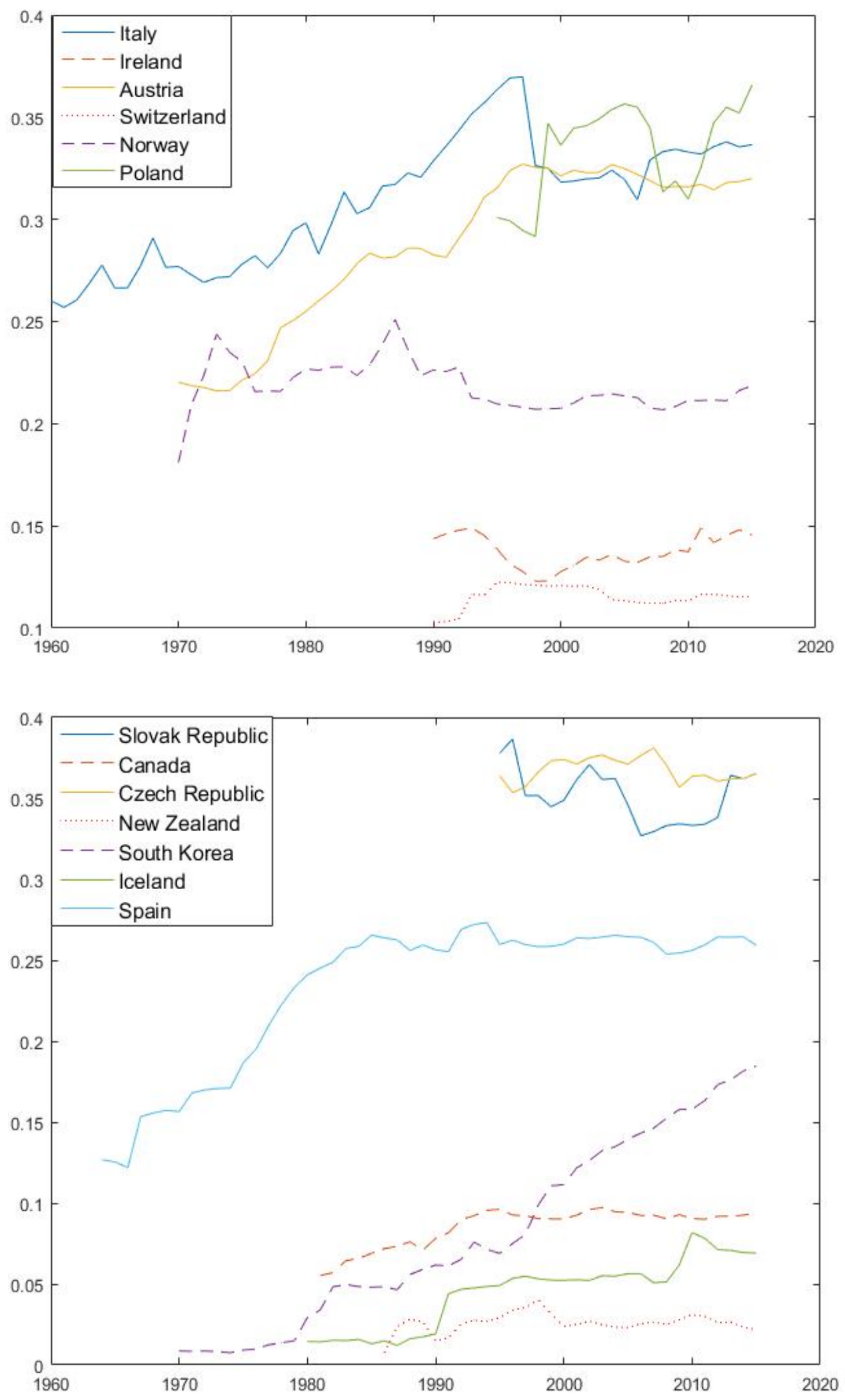
Figure 2: SSC schedules in 2015, six countries

a) Low threshold SSC funding systems

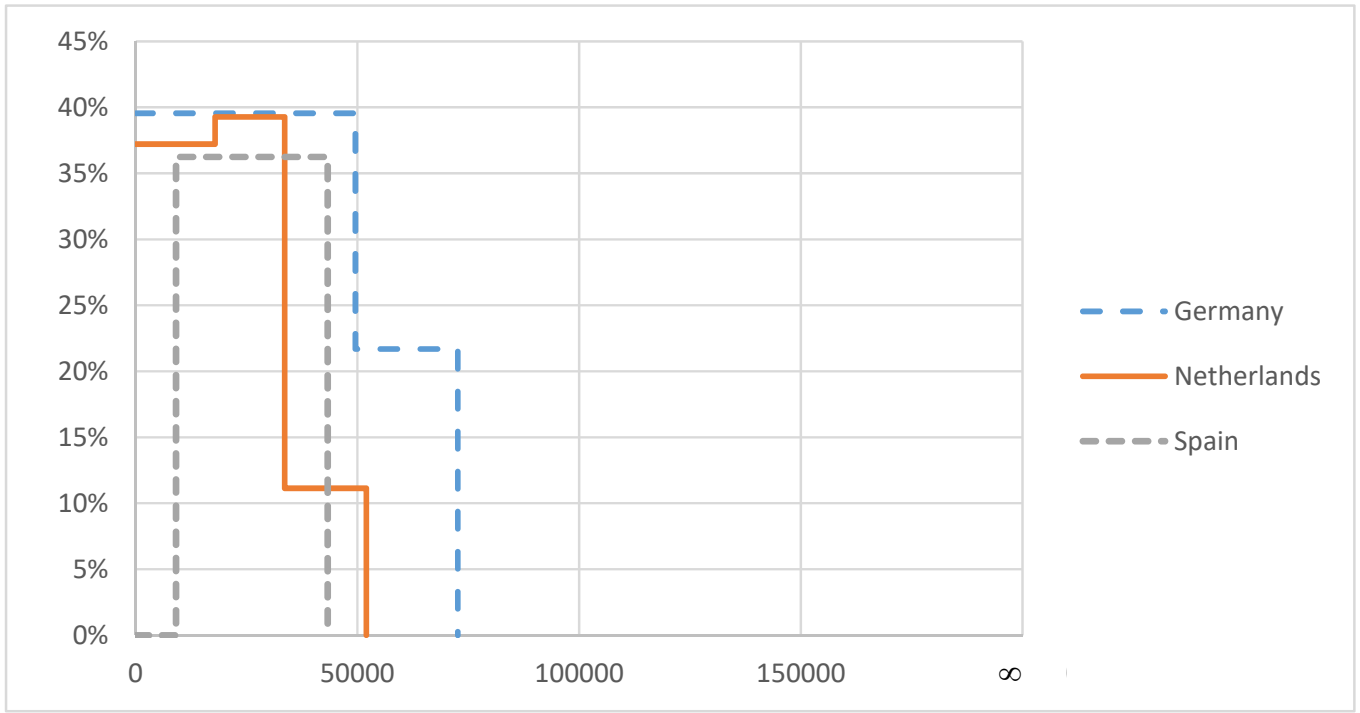

Gross annual income

b) High threshold SSC funding systems

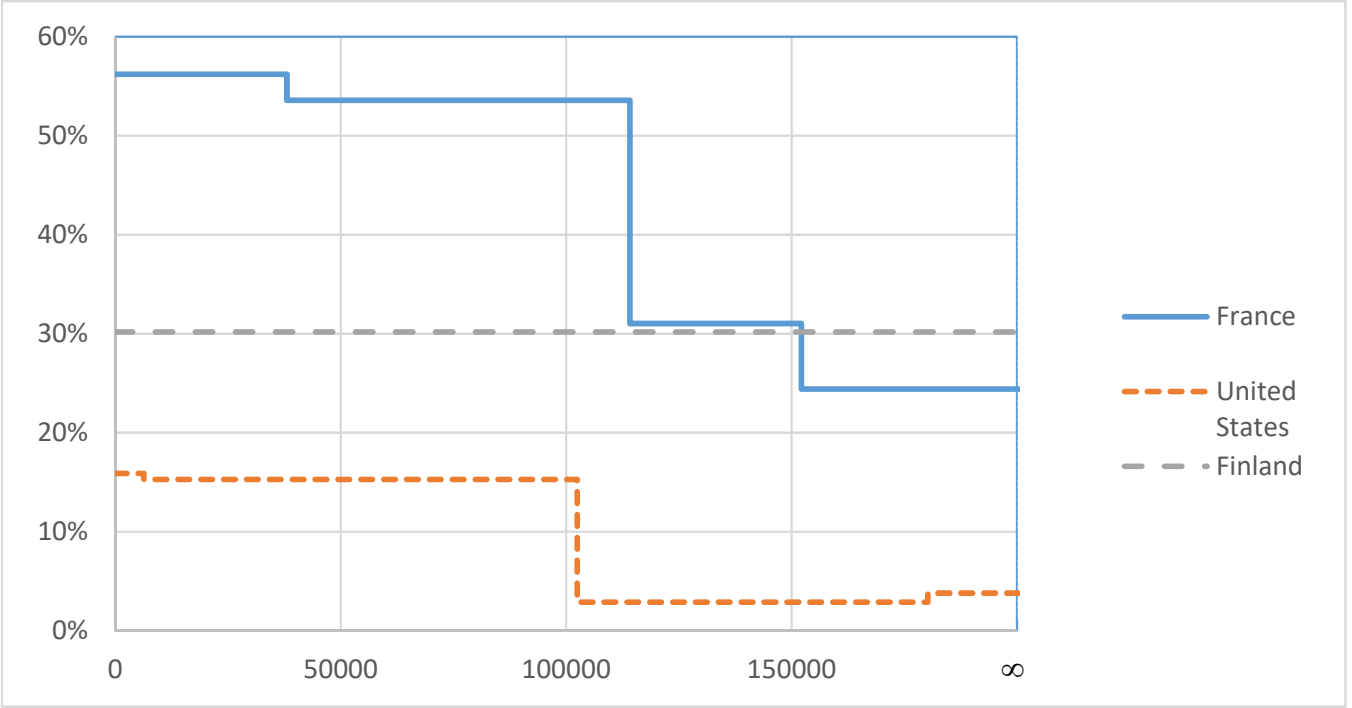

\section{Gross annual income}

Source: OECD, authors' calculations 
Figure 3: Overall average (solid line) and average marginal (dashed line) SSC rates (\%)
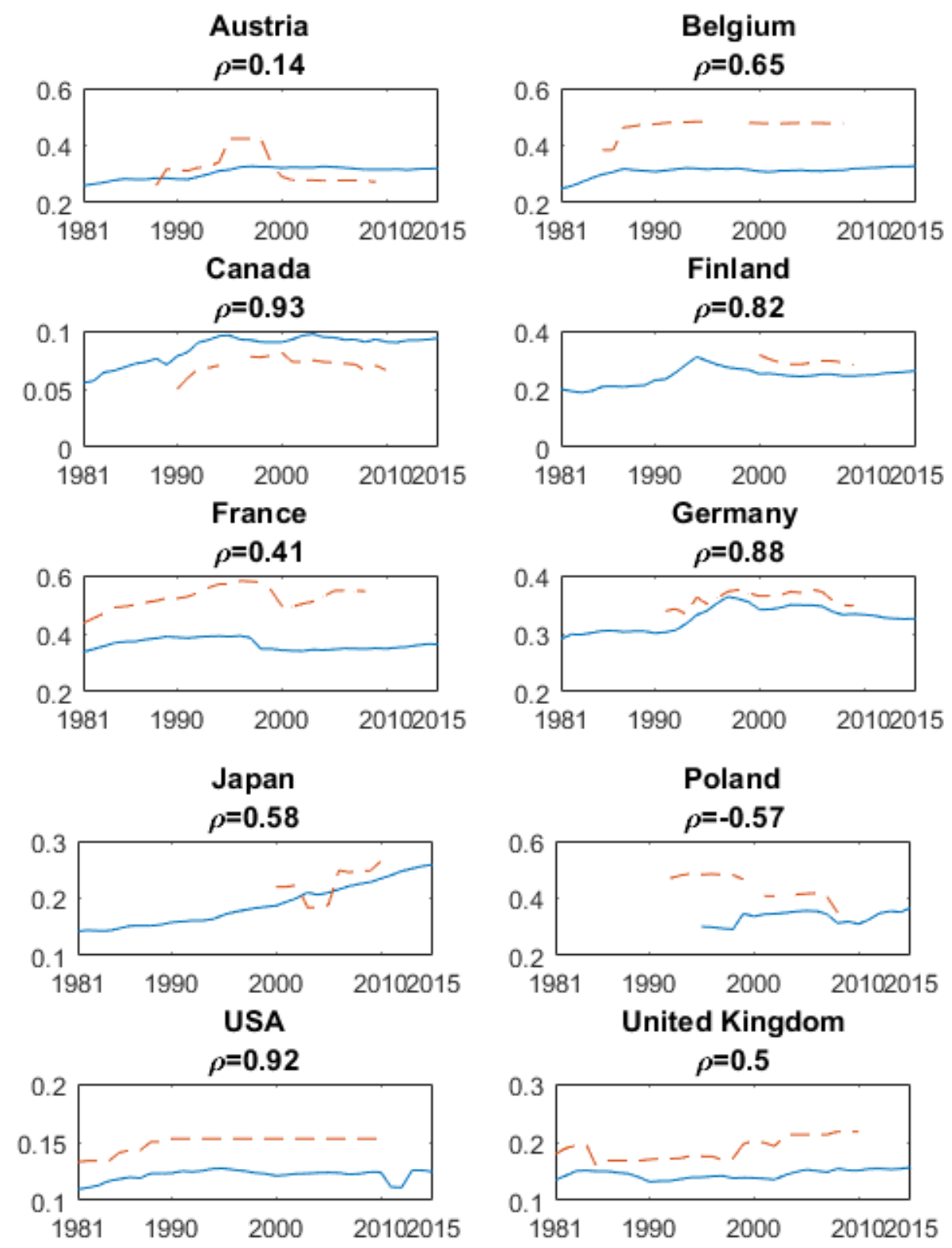

Note: Linear correlation coefficients are presented above each plot 
Figure 4: Total payroll taxes as a fraction of total compensation, Germany, 1970-2015

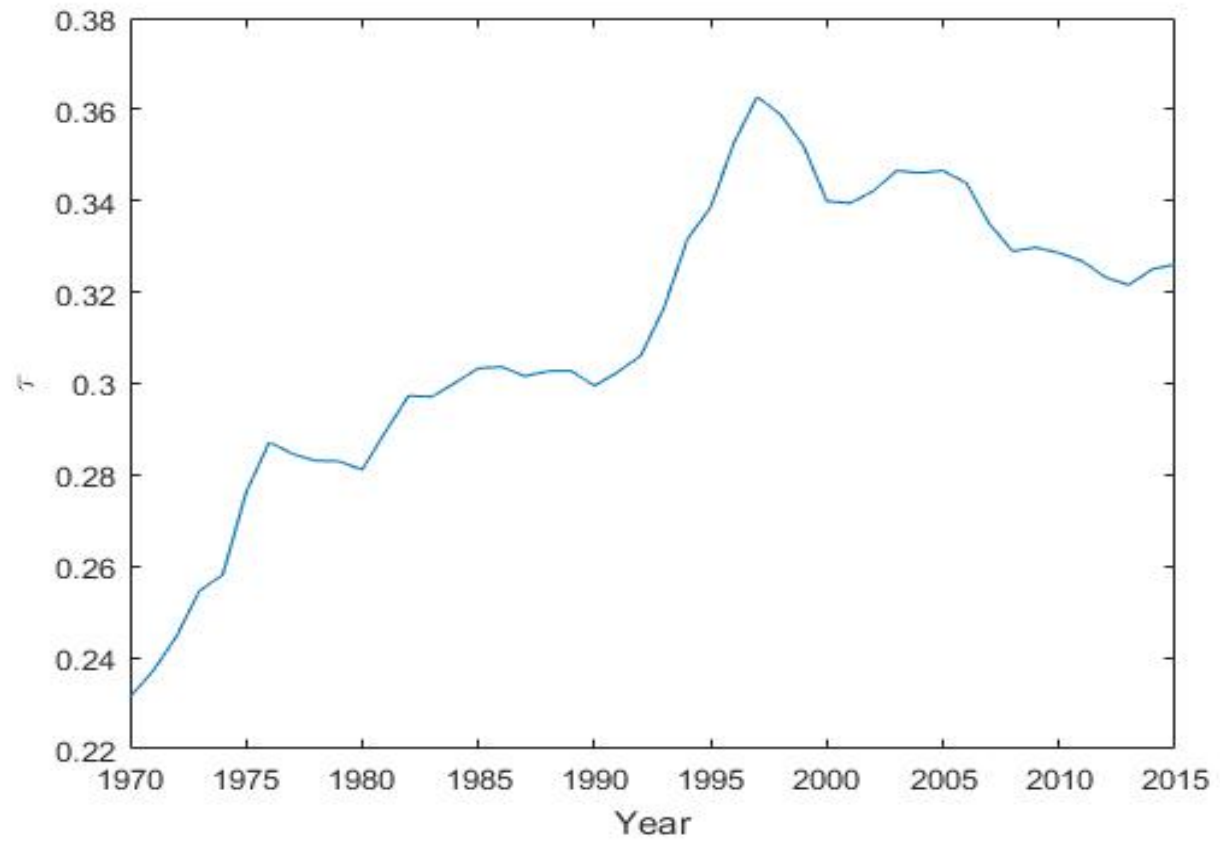

Note: Data for 1970-1990 are for West Germany only 
Figure 5: Cross-correlations of real growth and SSC rates

\begin{tabular}{|c|c|c|c|c|c|c|}
\hline Country & $\Delta \ln \left(Y_{t}\right), \tau_{t-i}$ & $\Delta \ln \left(Y_{t}\right)$ & $\tau_{t+i}$ & i & lag & lead \\
\hline Austria & 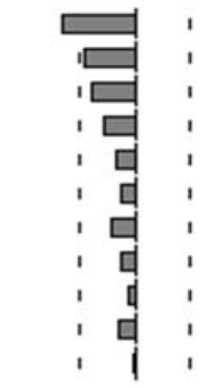 & 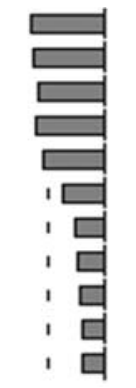 & $\begin{array}{l}1 \\
1 \\
1 \\
1 \\
1 \\
1 \\
1\end{array}$ & $\begin{array}{r}0 \\
1 \\
2 \\
3 \\
4 \\
5 \\
6 \\
7 \\
8 \\
9 \\
10\end{array}$ & $\begin{array}{l}-0.3944 \\
-0.2758 \\
-0.2310 \\
-0.1664 \\
-0.1056 \\
-0.0708 \\
-0.1275 \\
-0.0814 \\
-0.0377 \\
-0.0872 \\
-0.0113\end{array}$ & $\begin{array}{l}-0.3944 \\
-0.3824 \\
-0.3594 \\
-0.3646 \\
-0.3336 \\
-0.2143 \\
-0.1532 \\
-0.1394 \\
-0.1256 \\
-0.1168 \\
-0.1117\end{array}$ \\
\hline Belgium & $\begin{array}{ll} \\
1 \\
1\end{array}$ & (口) & $\begin{array}{l}1 \\
1 \\
1 \\
1 \\
1 \\
1 \\
1 \\
1 \\
1 \\
1 \\
1\end{array}$ & $\begin{array}{r}0 \\
1 \\
2 \\
3 \\
4 \\
5 \\
6 \\
7 \\
8 \\
9 \\
10\end{array}$ & $\begin{array}{l}-0.3448 \\
-0.1942 \\
-0.1697 \\
-0.0971 \\
-0.0483 \\
-0.0216 \\
-0.1253 \\
-0.0449 \\
-0.0806 \\
-0.0553 \\
-0.0410\end{array}$ & $\begin{array}{l}-0.3448 \\
-0.3395 \\
-0.3288 \\
-0.3077 \\
-0.3231 \\
-0.2356 \\
-0.2304 \\
-0.2151 \\
-0.2143 \\
-0.1895 \\
-0.1919\end{array}$ \\
\hline Canada & 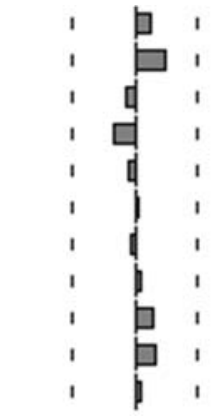 & 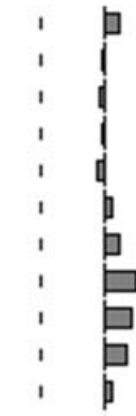 & $\begin{array}{l}1 \\
1 \\
1 \\
1 \\
1 \\
1 \\
1 \\
1 \\
1\end{array}$ & $\begin{array}{r}0 \\
1 \\
2 \\
3 \\
4 \\
5 \\
6 \\
7 \\
8 \\
9 \\
10\end{array}$ & $\begin{array}{r}0.0834 \\
0.1673 \\
-0.0523 \\
-0.1184 \\
-0.0388 \\
0.0243 \\
-0.0232 \\
0.0295 \\
0.1054 \\
0.1184 \\
0.0268\end{array}$ & $\begin{array}{r}0.0834 \\
-0.0117 \\
-0.0172 \\
-0.0162 \\
-0.0355 \\
0.0487 \\
0.0888 \\
0.1789 \\
0.1485 \\
0.1301 \\
0.0543\end{array}$ \\
\hline Denmark & 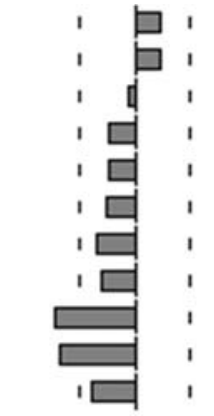 & $\begin{array}{ll}1 & \text { 口 } \\
1 & 0 \\
1 & 0 \\
1 & 0 \\
1 & 0 \\
1 & 0 \\
1 & 0 \\
1 & 0 \\
1 & 0 \\
1 & 0 \\
1 & 0\end{array}$ & $\begin{array}{l}1 \\
1 \\
1 \\
1 \\
1 \\
1 \\
1 \\
1 \\
1 \\
1 \\
1\end{array}$ & $\begin{array}{r}0 \\
1 \\
2 \\
3 \\
4 \\
5 \\
6 \\
7 \\
8 \\
9 \\
10\end{array}$ & $\begin{array}{r}0.1460 \\
0.1451 \\
-0.0334 \\
-0.1351 \\
-0.1366 \\
-0.1527 \\
-0.2090 \\
-0.1725 \\
-0.4424 \\
-0.4044 \\
-0.2364\end{array}$ & $\begin{array}{r}0.1460 \\
0.0985 \\
-0.0482 \\
-0.0661 \\
-0.0394 \\
0.0677 \\
0.0241 \\
-0.0156 \\
0.0120 \\
0.0104 \\
-0.0370\end{array}$ \\
\hline Finland & 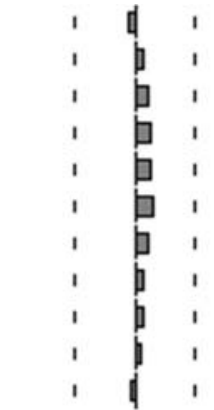 & (ם & $\begin{array}{l}1 \\
1 \\
1 \\
1 \\
1 \\
1 \\
1 \\
1 \\
1\end{array}$ & $\begin{array}{r}0 \\
1 \\
2 \\
3 \\
4 \\
5 \\
6 \\
7 \\
8 \\
9 \\
10\end{array}$ & $\begin{array}{r}-0.0353 \\
0.0447 \\
0.0796 \\
0.0874 \\
0.0828 \\
0.0931 \\
0.0809 \\
0.0449 \\
0.0503 \\
0.0325 \\
-0.0182\end{array}$ & $\begin{array}{r}-0.0353 \\
-0.1397 \\
-0.2221 \\
-0.2868 \\
-0.2386 \\
-0.0666 \\
0.0233 \\
0.0370 \\
0.0399 \\
0.0625 \\
0.0835\end{array}$ \\
\hline
\end{tabular}


Source: Authors' calculations

Figure 5 (continued): Cross-correlations of real growth and SSC rates

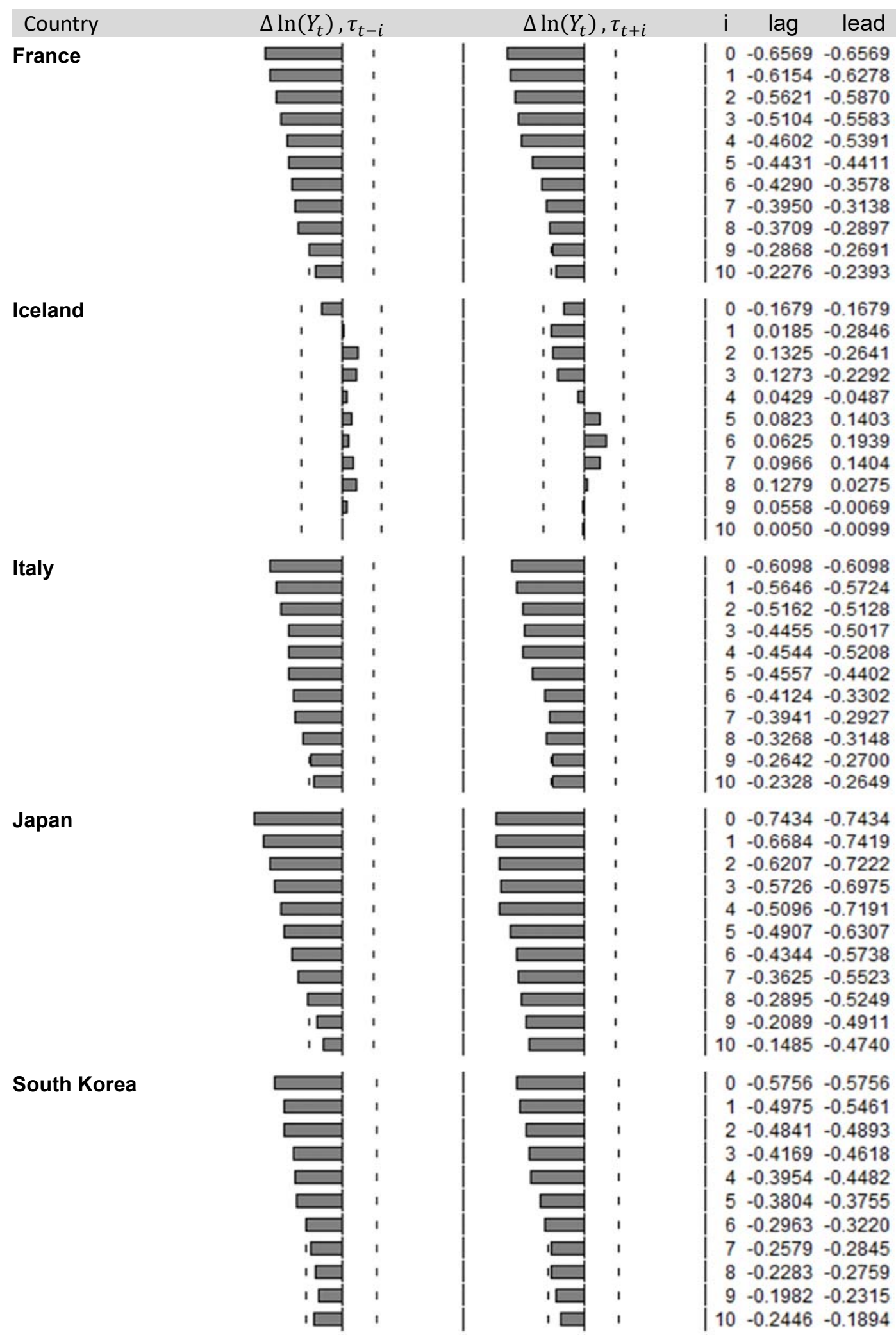

Source: Authors' calculations 
Figure 5 (continued): Cross-correlations of real growth and SSC rates

\begin{tabular}{|c|c|c|c|c|c|c|}
\hline Country & $\Delta \ln \left(Y_{t}\right), \tau_{t-i}$ & $\Delta \ln \left(Y_{t}\right.$ & $t), \tau_{t+i}$ & $\mathrm{i}$ & lag & lead \\
\hline Netherlands & ' $\quad$ I & 1 & $\square_{1}$ & 0 & 0.2347 & 0.2347 \\
\hline & $\square^{\prime}$ & 1 & 1 & 1 & 0.2918 & 0.0133 \\
\hline & $\square$ & 1 다 & 1 & 2 & 0.4095 & -0.1162 \\
\hline & 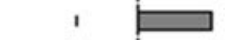 & $1 \square$ & 1 & 3 & 0.4025 & -0.2009 \\
\hline & 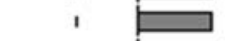 & $\square$ & 1 & 4 & 0.4091 & -0.2290 \\
\hline & $\square$ & $1 \square$ & 1 & 5 & 0.3922 & -0.1750 \\
\hline & $\square$ & $1 \square$ & 1 & 6 & 0.4295 & -0.1797 \\
\hline & $\square$ & 1 다 & 1 & 7 & 0.3955 & -0.1127 \\
\hline & י י & 1 다 & 1 & 8 & 0.2544 & -0.0840 \\
\hline & 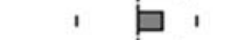 & 1 d & 1 & 9 & 0.1441 & -0.0649 \\
\hline & $\square$ י & , 口 & 1 & 10 & 0.2206 & -0.1381 \\
\hline New Zealand & י & 1 & 口 & 0 & 0.2783 & 0.2783 \\
\hline & $\square$ & 1 & 1 & 1 & 0.3825 & 0.0314 \\
\hline & ' & 1 & 1 & 2 & 0.0455 & 0.0475 \\
\hline & 1 & 1 & 曰 & 3 & -0.0391 & 0.1304 \\
\hline & $\square \quad 1$ & 1 & 口 & 4 & 0.1653 & 0.1181 \\
\hline & 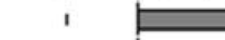 & 1 口 & 1 & 5 & 0.5158 & -0.1430 \\
\hline & 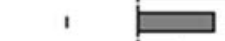 & $\square$ & 1 & 6 & 0.4247 & -0.4346 \\
\hline & $\square 1$ & $\square$ & 1 & 7 & 0.2318 & -0.4513 \\
\hline & b 1 & $\square$ & 1 & 8 & 0.0477 & -0.3054 \\
\hline & di & $1 \square$ & 1 & 9 & -0.0598 & -0.2431 \\
\hline & , 口 & $1 \square$ & 1 & 10 & -0.1404 & -0.2125 \\
\hline Norway & 口， & 1 & 口 & 0 & 0.1026 & 0.1026 \\
\hline & 1 id & 1 & 曰 & 1 & -0.0440 & 0.1578 \\
\hline & b & 1 & יו & 2 & 0.0379 & 0.2143 \\
\hline & 曰， & 1 & 口 & 3 & 0.1292 & 0.1550 \\
\hline & $\square 1$ & 1 & 1 & 4 & 0.1850 & 0.0632 \\
\hline & 口， & 1 & 1 & 5 & 0.1522 & 0.0071 \\
\hline & 口 1 & 1 & 口 & 6 & 0.1035 & 0.1135 \\
\hline & 口 1 & 1 & $\square$ & 7 & 0.1146 & 0.2341 \\
\hline & 口， & 1 & י & 8 & 0.1227 & 0.2420 \\
\hline & 巨。 & 1 & $\square$ । & 9 & 0.1716 & 0.1873 \\
\hline & $\longmapsto$ & 1 & $\square$ । & 10 & 0.3223 & 0.1949 \\
\hline Spain & 1 & & 1 & 0 & -0.5931 & -0.5931 \\
\hline & 1 & $\square$ & 1 & 1 & -0.5273 & -0.5617 \\
\hline & 1 & $\square$ & 1 & 2 & -0.4708 & -0.4947 \\
\hline & $\sqsubset$ & $\square$ & 1 & 3 & -0.4099 & -0.4353 \\
\hline & $\square$ & $\square$ & 1 & 4 & -0.3680 & -0.3831 \\
\hline & $\sqsubset$ & $\sqsubset$ & 1 & 5 & -0.2916 & -0.2873 \\
\hline & I & $\square$ & 1 & 6 & -0.2117 & -0.2238 \\
\hline & 1[ & $1 \square$ & 1 & 7 & -0.1982 & -0.1881 \\
\hline & 맘 & $\square$ & 1 & 8 & -0.1670 & -0.1729 \\
\hline & 1 d & 1 마 & 1 & 9 & -0.0496 & -0.1349 \\
\hline & $1 \quad p$ & 1 다 & 1 & 10 & 0.0410 & -0.0999 \\
\hline Sweden & ᄃ & $\sqsubset$ & 1 & 0 & -0.2927 & -0.2927 \\
\hline & '당 & ᄃ & 1 & 1 & -0.2448 & -0.3236 \\
\hline & ' & ᄃ & 1 & 2 & -0.2240 & -0.3089 \\
\hline & $1 \square$ & ᄃ & 1 & 3 & -0.1790 & -0.2941 \\
\hline & 1 다 & ᄃ & 1 & 4 & -0.1172 & -0.2587 \\
\hline & 1 단 & $\sqsubset$ & 1 & 5 & -0.0832 & -0.3323 \\
\hline & 1 . & $\square$ & 1 & 6 & -0.0707 & -0.3265 \\
\hline & 1 다 & $\square$ & 1 & 7 & -0.0860 & -0.2891 \\
\hline & 듬 & $\square$ & 1 & 8 & -0.1056 & -0.2360 \\
\hline & 1 다 & $\square$ & 1 & 9 & -0.0743 & -0.2050 \\
\hline & 17 & $1 \square$ & 1 & 10 & 0.0236 & -0.1567 \\
\hline
\end{tabular}

Source: Authors' calculations 
Figure 5 (continued): Cross-correlations of real growth and SSC rates

\begin{tabular}{|c|c|c|c|c|c|c|}
\hline Country & $\Delta \ln \left(Y_{t}\right), \tau_{t-i}$ & $\Delta \ln \left(Y_{t}\right)$ & $\tau_{t+i}$ & $\mathrm{i}$ & lag & lead \\
\hline United Kingdom & 1 d 1 & 10 & 1 & 0 & -0.0456 & -0.0456 \\
\hline & 1 & 1 可 & I & & -0.0107 & -0.1090 \\
\hline & 10 & ' 口 & ' & & -0.0306 & -0.1854 \\
\hline & 1 d & ' 口 & 1 & 3 & -0.0744 & -0.1651 \\
\hline & 11 & 담 & 1 & 4 & -0.0147 & -0.1193 \\
\hline & 1 d & 14 & 1 & & -0.0795 & -0.0316 \\
\hline & 1 d & 11 & ' & 6 & -0.0766 & -0.0102 \\
\hline & 1 & 1 & 1 & 7 & -0.0192 & -0.0058 \\
\hline & 1 & ' & ' & 8 & 0.0045 & 0.0370 \\
\hline & 1 & ' & ' & 9 & 0.1020 & 0.1046 \\
\hline & ' 曰 & E & 1 & 10 & 0.1789 & 0.1750 \\
\hline USA & $\square$ & $\square$ & 1 & 0 & -0.2883 & -0.2883 \\
\hline & ᄃ & $\square$ & 1 & 1 & -0.3311 & -0.2662 \\
\hline & 1 & $\square$ & 1 & 2 & -0.2425 & -0.2406 \\
\hline & $\square$ & 口 & ' & 3 & -0.2298 & -0.2194 \\
\hline & 망 & $\square$ & ' & 4 & -0.1916 & -0.2319 \\
\hline & 면 & 口 & 1 & & -0.1254 & -0.2123 \\
\hline & 1 & 口 & 1 & 6 & -0.0874 & -0.2140 \\
\hline & d & , 口 & 1 & 7 & -0.1101 & -0.1492 \\
\hline & 1 d & 1 d & ' & 8 & -0.0638 & -0.0965 \\
\hline & $1 d$ & 1 d & 1 & 9 & -0.0279 & -0.0604 \\
\hline & 14 & 10 & ' & 10 & -0.0564 & -0.0272 \\
\hline
\end{tabular}

Source: Authors' calculations 
Figure 6: Sources of changes in average SSC rates (\%)
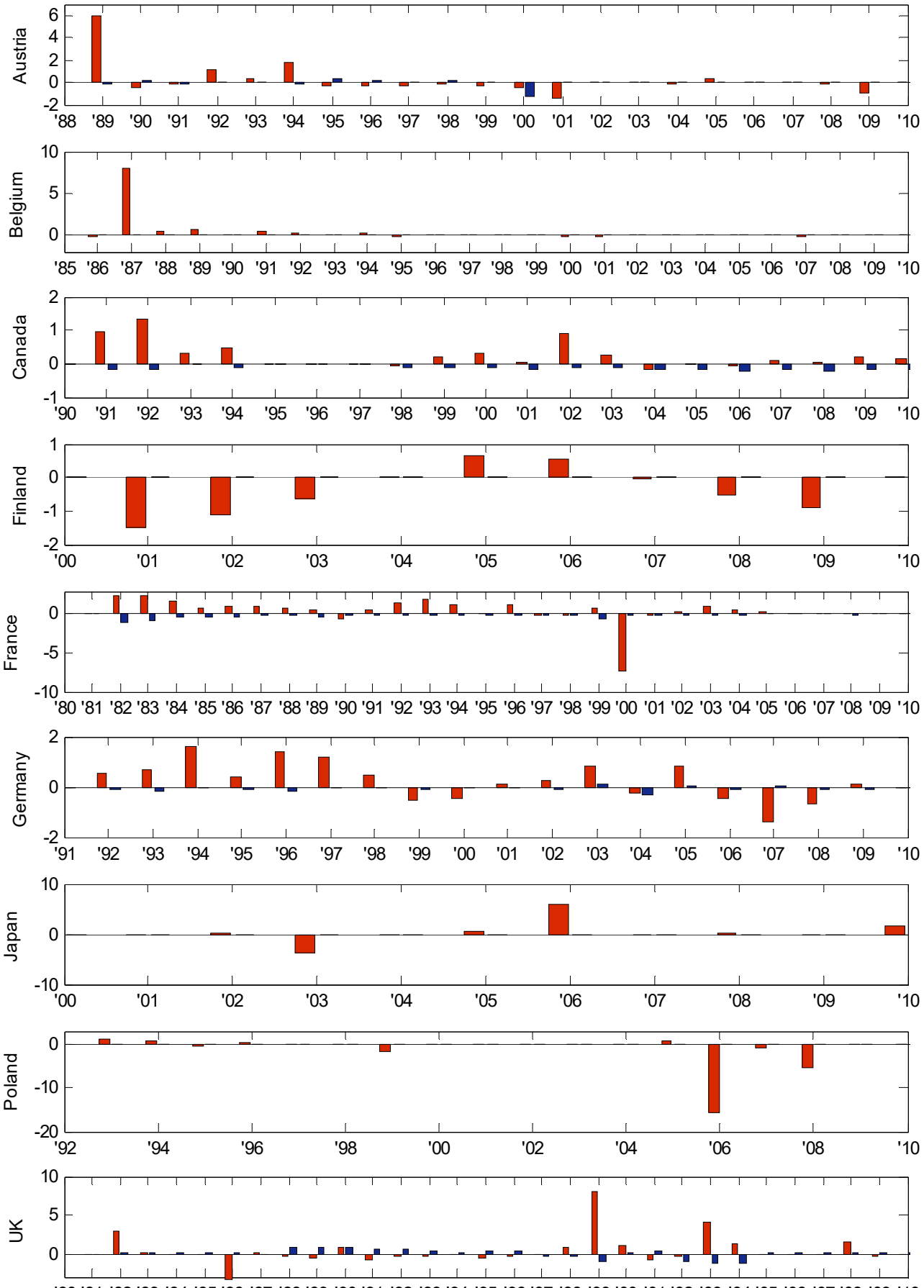

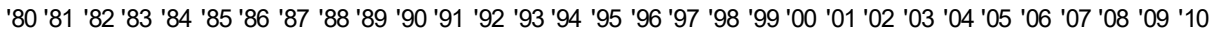

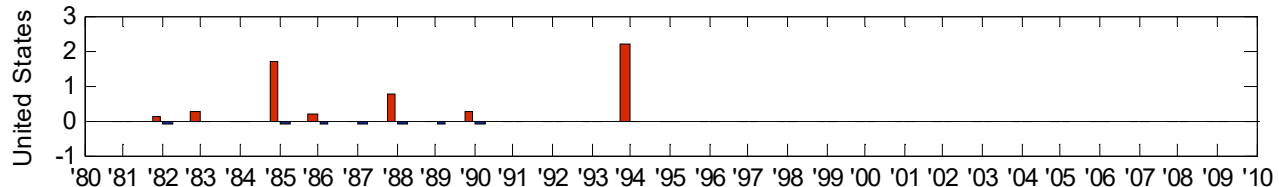

Note: Red bars denote changes in average SSC rates due to changes in the tax code, holding the distribution of earnings constant. Blue bars denote the changes in average payroll taxation implied by changes in the earnings distribution, defined as average SSC implied by the nine deciles of the distribution minus percentage change due to changes in the tax code. 
Figure 7: Two SSC schedules over time: Germany and France
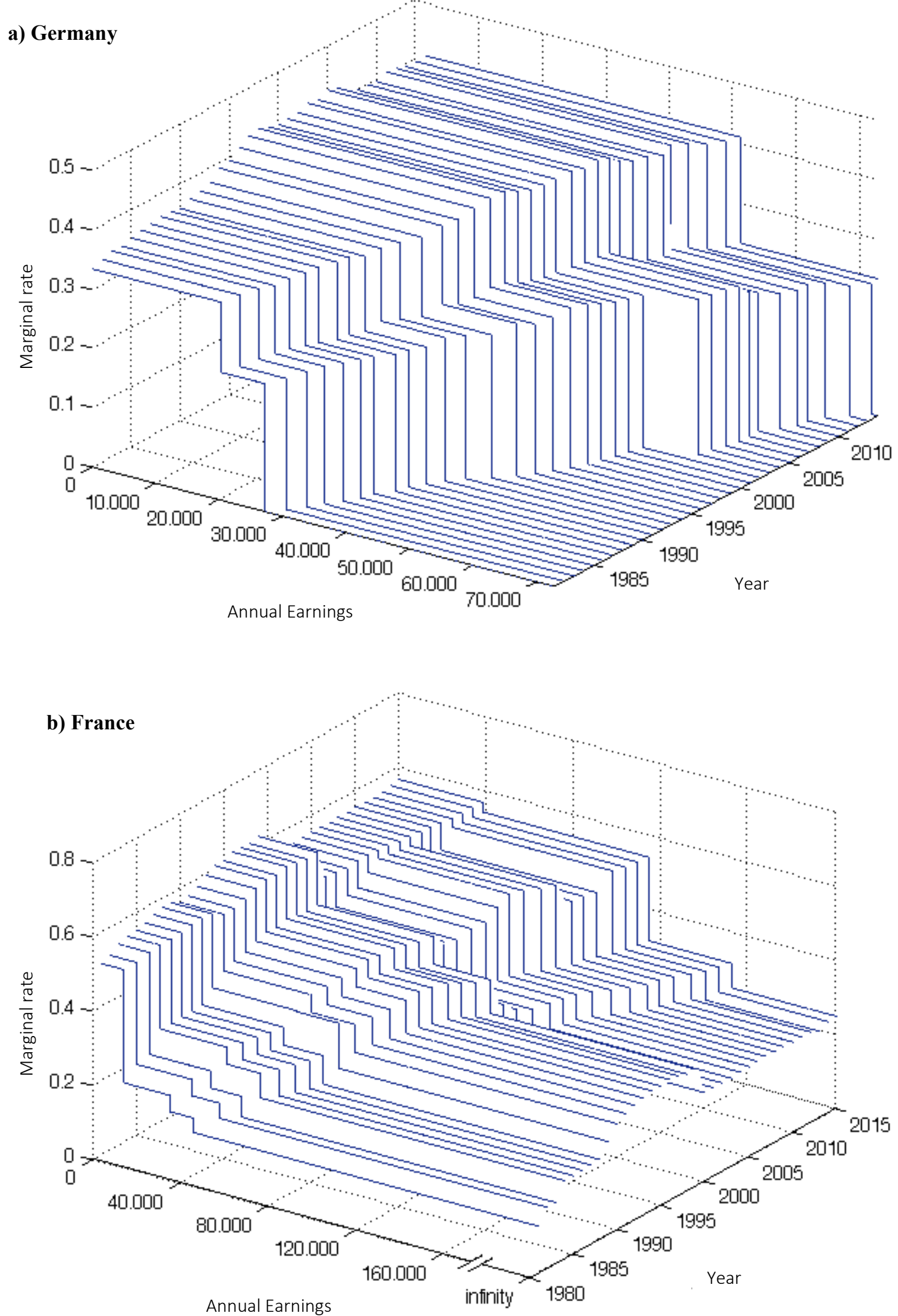
Table 1: Dimension of social security systems in 2015 (\%)

\begin{tabular}{lccc}
\hline Country & $\begin{array}{c}\text { SSC as } \% \\
\text { of GDP }\end{array}$ & $\begin{array}{c}\text { SSC as \% of wage } \\
\left.\text { bill (SSC rate, } \tau^{\mathrm{A}}\right)\end{array}$ & $\begin{array}{c}\text { SSC as \% } \\
\text { of taxes }\end{array}$ \\
\hline USA & 7.4 & 12.5 & 23.7 \\
Canada & 5.4 & 9.4 & 15.3 \\
New Zealand & 1.1 & 2.2 & 0.0 \\
Germany & 18.0 & 32.6 & 37.9 \\
Sweden & 3.7 & 7.8 & 22.5 \\
France & 19.7 & 36.3 & 37.1 \\
Netherlands & 15.2 & 30.0 & 37.7 \\
United Kingdom & 8.0 & 15.7 & 18.6 \\
Denmark & 1.1 & 1.9 & 0.1 \\
Greece & 13.2 & 41.4 & 29.0 \\
Finland & 14.4 & 26.3 & 29.0 \\
Hungary & 18.4 & 32.0 & 33.3 \\
Japan & 12.5 & 25.9 & n.a. \\
Belgium & 16.7 & 32.8 & 31.9 \\
Italy & 14.1 & 33.6 & 30.2 \\
Ireland & 4.7 & 14.5 & 9.7 \\
Austria & 16.8 & 32.0 & 34.0 \\
Switzerland & 6.8 & 11.5 & 24.6 \\
Norway & 10.2 & 21.9 & 27.4 \\
Poland & 14.5 & 36.6 & n.a. \\
Slovak Republic & 14.5 & 36.5 & 42.8 \\
Czech Republic & 15.5 & 36.5 & 43.3 \\
South Korea & 8.2 & 18.5 & 16.6 \\
Iceland & 6.3 & 6.9 & 33.7 \\
Spain & 12.4 & 25.9 & . \\
Source: OECD Economic Outlook 95, OECD revenue statistics and authors calculations. \\
\end{tabular}


Table 2: Average SSC rates: Means, standard deviations and cyclical correlations, 1960-2015*

\begin{tabular}{|c|c|c|c|c|c|c|c|}
\hline \multirow[t]{2}{*}{ Country } & \multicolumn{2}{|c|}{$\begin{array}{l}\text { Average SSC tax } \\
\text { rate }\left(\tau^{A}\right)\end{array}$} & \multicolumn{2}{|c|}{$\begin{array}{l}\text { Standard deviation } \\
\text { of } \tau^{\mathrm{A}}(\%)\end{array}$} & \multicolumn{3}{|c|}{$\begin{array}{l}\text { Correlation of HP-filtered } \tau^{\mathrm{A}} \\
\text { with HP-filtered GDP* }\end{array}$} \\
\hline & $1960-90$ & $1991-2015$ & $1960-1990$ & $1991-2015$ & $1960-1990$ & $1991-2015$ & $1960-2015$ \\
\hline USA & 0.09 & 0.12 & 2.3 & 0.4 & 0.31 & -0.20 & 0.10 \\
\hline Germany & 0.28 & 0.34 & 2.3 & 1.5 & -0.61 & -0.48 & -0.53 \\
\hline Sweden & 0.09 & 0.10 & 2.9 & 2.5 & -0.38 & 0.07 & -0.06 \\
\hline France & 0.31 & 0.36 & 4.9 & 1.9 & -0.19 & -0.28 & -0.23 \\
\hline Netherlands & 0.30 & 0.30 & 4.2 & 1.9 & -0.50 & 0.22 & -0.06 \\
\hline United Kingdom & 0.13 & 0.15 & 1.6 & 0.8 & -0.47 & 0.22 & -0.27 \\
\hline Denmark & 0.02 & 0.03 & 0.6 & 0.7 & -0.11 & 0.25 & 0.07 \\
\hline Greece & n.a. & 0.37 & n.a. & 2.0 & n.a. & -0.32 & -0.32 \\
\hline Finland & 0.15 & 0.26 & 5.4 & 1.8 & -0.45 & -0.11 & -0.31 \\
\hline Hungary & n.a. & 0.30 & n.a. & 1.6 & n.a. & 0.43 & 0.43 \\
\hline Japan & 0.11 & 0.21 & 2.9 & 3.2 & -0.28 & 0.27 & -0.08 \\
\hline Belgium & 0.26 & 0.32 & 3.3 & 0.6 & -0.72 & -0.60 & -0.66 \\
\hline Italy & 0.29 & 0.34 & 2.1 & 1.6 & 0.07 & -0.07 & 0.01 \\
\hline Ireland & n.a. & 0.14 & 0.0 & 0.8 & n.a. & -0.28 & -0.30 \\
\hline Austria & 0.25 & 0.32 & 2.8 & 1.1 & -0.38 & -0.50 & -0.44 \\
\hline Switzerland & n.a. & 0.12 & 0.0 & 0.5 & n.a. & -0.10 & -0.10 \\
\hline Norway & 0.23 & 0.21 & 1.4 & 0.5 & 0.24 & -0.19 & 0.15 \\
\hline Poland & n.a. & 0.33 & n.a. & 2.3 & n.a. & -0.15 & -0.15 \\
\hline Slovak Republic & n.a. & 0.35 & n.a. & 1.7 & n.a. & -0.27 & -0.27 \\
\hline Canada & 0.07 & 0.09 & 0.8 & 0.3 & -0.28 & -0.26 & -0.28 \\
\hline Czech Republic & n.a. & 0.37 & n.a. & 0.7 & n.a. & 0.29 & 0.29 \\
\hline New Zealand & 0.02 & 0.03 & 0.9 & 0.5 & -0.41 & -0.08 & -0.09 \\
\hline South Korea & 0.03 & 0.12 & 2.1 & 4.0 & -0.12 & -0.82 & -0.47 \\
\hline Iceland & 0.02 & 0.06 & 0.2 & 1.0 & -0.39 & -0.62 & -0.57 \\
\hline Spain & 0.21 & 0.26 & 5.0 & 0.5 & -0.50 & -0.47 & -0.47 \\
\hline
\end{tabular}

Source: OECD Economic Outlook 95 and authors' calculations

Note: Data series start form 1960 or from the earliest available year.

* HP-filter with $\lambda=6.25$ (see Ravn and Uhlig, 2002). 
Table 3: Correlation between average SSC rates and log-output 1960*-2015

\begin{tabular}{|c|c|c|c|c|c|c|c|c|}
\hline \multirow[b]{3}{*}{ Country } & \multicolumn{5}{|c|}{ Correlation coefficients } & \multirow{2}{*}{\multicolumn{2}{|c|}{ Range }} & \multirow[b]{3}{*}{$B P(3,7)$} \\
\hline & \multirow[t]{2}{*}{$H P$} & \multirow[t]{2}{*}{ Diff } & \multirow{2}{*}{$\begin{array}{c}B P \\
(2,8) \\
\end{array}$} & \multirow{2}{*}{$\begin{array}{c}B P \\
(3,7)\end{array}$} & & & & \\
\hline & & & & & $H P$ & Diff & $B P(2,8)$ & \\
\hline USA & 0.10 & 0.20 & 0.07 & 0.02 & 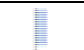 & & & \\
\hline Germany & -0.52 & -0.19 & -0.50 & -0.52 & 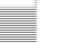 & 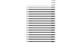 & & 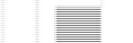 \\
\hline Sweden & -0.06 & -0.08 & -0.04 & -0.05 & 1 & 衰 & & \\
\hline France & -0.23 & 0.02 & -0.01 & 0.01 & 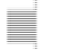 & & & \\
\hline Netherlands & -0.06 & -0.06 & 0.17 & 0.03 & $\sqrt{1}$ & 1 & 害 & \\
\hline United Kingdom & -0.27 & -0.17 & -0.32 & -0.22 & 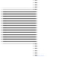 & 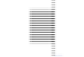 & 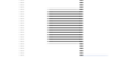 & 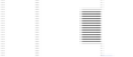 \\
\hline Denmark & 0.07 & 0.06 & 0.26 & 0.13 & & & 䜺 & 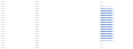 \\
\hline Greece & -0.32 & -0.37 & -0.05 & -0.12 & 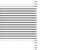 & 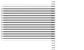 & & 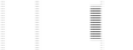 \\
\hline Finland & -0.31 & -0.26 & -0.01 & 0.11 & & & & $\underline{1}$ \\
\hline Hungary & 0.43 & 0.10 & 0.54 & 0.63 & & & & 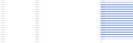 \\
\hline Japan & -0.08 & -0.21 & -0.05 & -0.15 & 1 & 唫 & & 践 \\
\hline Belgium & -0.66 & -0.50 & -0.56 & -0.56 & $=$ & 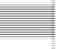 & & 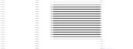 \\
\hline Italy & 0.01 & 0.01 & 0.09 & 0.12 & & & & 譍 \\
\hline Ireland & -0.30 & -0.30 & 0.09 & 0.36 & 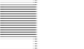 & 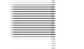 & & 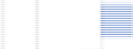 \\
\hline Austria & -0.44 & -0.29 & -0.34 & -0.27 & 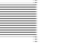 & 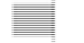 & 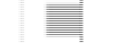 & 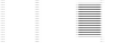 \\
\hline Switzerland & -0.10 & -0.36 & 0.22 & 0.44 & 戜 & 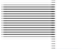 & 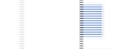 & 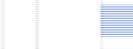 \\
\hline Norway & 0.15 & 0.17 & 0.32 & 0.42 & 訾 & & 霊 & 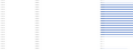 \\
\hline Poland & -0.15 & -0.22 & 0.10 & 0.29 & 垶 & 簑 & & 辯 \\
\hline Slovak Republic & -0.27 & -0.28 & -0.01 & 0.03 & 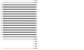 & 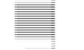 & & \\
\hline Canada & -0.28 & -0.21 & -0.16 & -0.48 & 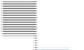 & 玨 & 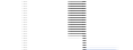 & 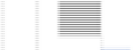 \\
\hline Czech Republic & 0.29 & 0.21 & 0.33 & 0.34 & & & & 塹 \\
\hline New Zealand & -0.09 & -0.23 & -0.17 & -0.43 & 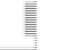 & 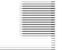 & 唫 & 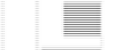 \\
\hline South Korea & -0.47 & -0.42 & -0.50 & -0.69 & 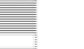 & 型 & 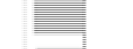 & 售 \\
\hline Iceland & -0.57 & -0.51 & -0.47 & -0.46 & & 烈 & 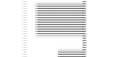 & 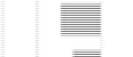 \\
\hline Spain & -0.47 & -0.16 & -0.25 & -0.32 & & 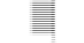 & 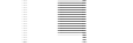 & 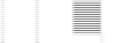 \\
\hline
\end{tabular}

Notes: $H P=$ data detrended using Hodrick Prescott filter; Diff: =first differenced data; $B P=$ data detrended using the bandpass filter with lower and upper periodicity parameters $(x, y)$.

Source: OECD, authors' calculations 
Table 4: Dynamic correlation between average SSC rates and log-output 1960*-2015

\begin{tabular}{|c|c|c|c|c|c|c|}
\hline \multirow[t]{2}{*}{ Country } & \multicolumn{2}{|c|}{ HP-Filter, $\lambda=6.25$} & \multicolumn{2}{|c|}{ First Differences } & \multicolumn{2}{|c|}{$\begin{array}{c}\text { Band-Pass Filter, } \\
1=2 \text { years, } \mathrm{u}=8 \text { years }\end{array}$} \\
\hline & $\rho\left(\tau_{t-1}, y_{t}\right)$ & $\rho\left(\tau_{\mathrm{t}+1}, \mathrm{y}_{\mathrm{t}}\right)$ & $\rho\left(\tau_{t-1}, y_{t}\right)$ & $\rho\left(\tau_{t+1}, y_{t}\right)$ & $\rho\left(\tau_{t-1}, y_{t}\right)$ & $\rho\left(\tau_{t+1}, y_{t}\right)$ \\
\hline USA & -0.26 & 0.17 & -0.16 & 0.14 & -0.38 & 0.24 \\
\hline Germany & -0.08 & -0.54 & 0.11 & -0.21 & 0.02 & -0.53 \\
\hline Sweden & -0.06 & -0.02 & -0.08 & -0.06 & -0.11 & 0.08 \\
\hline France & -0.01 & -0.14 & 0.15 & 0.08 & 0.02 & 0.14 \\
\hline Netherlands & 0.08 & -0.39 & -0.09 & -0.35 & 0.23 & -0.25 \\
\hline United Kingdom & 0.08 & -0.45 & -0.01 & -0.28 & 0.06 & -0.46 \\
\hline Denmark & 0.29 & -0.15 & 0.31 & -0.04 & 0.48 & -0.05 \\
\hline Greece & 0.09 & -0.52 & -0.22 & -0.52 & 0.40 & -0.52 \\
\hline Finland & -0.23 & -0.29 & -0.22 & -0.23 & -0.05 & -0.01 \\
\hline Hungary & -0.24 & 0.42 & -0.38 & 0.08 & -0.30 & 0.45 \\
\hline Japan & 0.06 & -0.20 & -0.14 & -0.32 & -0.01 & -0.07 \\
\hline Belgium & -0.05 & -0.29 & 0.09 & -0.15 & 0.21 & -0.03 \\
\hline Italy & -0.08 & 0.06 & -0.01 & 0.03 & -0.13 & 0.23 \\
\hline Ireland & -0.20 & -0.08 & -0.25 & -0.24 & 0.16 & 0.06 \\
\hline Austria & 0.10 & -0.30 & 0.11 & -0.06 & 0.24 & -0.11 \\
\hline Switzerland & -0.17 & -0.02 & -0.25 & -0.10 & 0.06 & 0.33 \\
\hline Norway & -0.15 & 0.20 & 0.00 & 0.15 & -0.14 & 0.42 \\
\hline Poland & -0.03 & -0.17 & -0.09 & -0.16 & 0.22 & -0.04 \\
\hline Slovak Republic & -0.26 & -0.19 & -0.29 & -0.30 & -0.24 & 0.17 \\
\hline Canada & 0.04 & -0.40 & 0.04 & -0.32 & 0.12 & -0.17 \\
\hline Czech Republic & 0.42 & -0.22 & 0.36 & -0.34 & 0.48 & -0.32 \\
\hline New Zealand & 0.42 & -0.12 & 0.24 & -0.17 & 0.58 & -0.56 \\
\hline South Korea & -0.08 & -0.05 & -0.28 & -0.21 & -0.15 & 0.12 \\
\hline Iceland & -0.29 & -0.40 & -0.32 & -0.36 & 0.02 & -0.44 \\
\hline Spain & -0.07 & -0.26 & 0.01 & 0.04 & 0.26 & -0.09 \\
\hline
\end{tabular}

Source: OECD Economic Outlook 95 and authors' calculations

Note: $\rho\left(\mathrm{x}_{t-i}, \mathrm{y}_{t}\right)$ denotes simple correlation between time dated variables $\mathrm{x}_{t-i}$ and $\mathrm{y}_{t}$. SSC rates and log of real GDP were HPfiltered with smoothing parameter 6.25. Data starts from 1960 or from the earliest available year. 
Table 5: Decomposition of annual changes in synthetic average SSC rates $\left(\Delta \tau_{t}^{A *}\right)$

\begin{tabular}{lccccc}
\hline Country (period) & $\begin{array}{c}(1) \\
\text { Mean absolute } \\
\text { value of } \Delta \tau_{t}^{A *} \\
\text { over period }\end{array}$ & $\begin{array}{c}(2) \\
\text { Mean absolute } \\
\text { value of } \Delta \tau_{t}^{S} \\
\text { over period }\end{array}$ & $\begin{array}{c}(3) \\
\left.\% \text { of var( } \Delta \tau_{t}^{A *}\right) \\
\text { accounted for by } \\
\Delta \tau_{t}^{S}\end{array}$ & $\begin{array}{c}(4) \\
\text { Mean absolute } \\
\text { value of } \Delta \tau_{t}^{D} \\
\text { over period }\end{array}$ & $\begin{array}{c}\text { \% of var }\left(\Delta \tau_{t}^{A *}\right) \\
\text { accounted for } \\
\text { by } \Delta \tau_{t}^{D}\end{array}$ \\
\hline Austria (1988-2009) & 0.73 & 0.70 & 96.3 & 0.13 & 3.9 \\
Belgium (1984-2008) & 0.58 & 0.58 & 100.0 & 0.00 & 0.0 \\
Canada (1990-2010) & 0.31 & 0.33 & 98.6 & 0.15 & 8.5 \\
Finland (2000-2009) & 0.65 & 0.65 & 100.0 & 0.00 & 0.0 \\
France (1982-2006) & 0.91 & 1.06 & 98.2 & 0.20 & 3.3 \\
Germany (1991-2009) & 0.66 & 0.67 & 98.3 & 0.11 & 0.2 \\
Japan (2000-2010) & 1.31 & 1.31 & 100.0 & 0.00 & 0.0 \\
Poland (1992-2008) & 2.25 & 2.25 & 100.0 & 0.00 & 0.0 \\
UK (1982-2010) & 0.90 & 1.02 & 91.9 & 0.43 & 6.9 \\
USA (1982-2010) & 0.19 & 0.19 & 99.7 & 0.04 & 0.2 \\
\hline
\end{tabular}

Table 6: Correlation of the first difference in average SSC rate with first differences of labor wedge, two measurements

\begin{tabular}{lcc}
\hline Country & $\begin{array}{c}\text { Authors' } \\
\text { calculations }\end{array}$ & $\begin{array}{c}\text { Brinca et al. } \\
(2016) \text { measure }\end{array}$ \\
\hline USA & -0.07 & 0.06 \\
Germany & 0.52 & 0.02 \\
Sweden & 0.18 & -0.11 \\
France & 0.29 & 0.25 \\
Netherlands & 0.46 & 0.26 \\
United Kingdom & 0.32 & 0.32 \\
Denmark & 0.39 & 0.40 \\
Greece & 0.29 & n.a. \\
Finland & 0.24 & 0.54 \\
Hungary & 0.05 & n.a. \\
Japan & 0.14 & -0.05 \\
Belgium & 0.28 & 0.26 \\
Italy & 0.39 & 0.40 \\
Ireland & 0.10 & -0.06 \\
Austria & 0.04 & 0.32 \\
Switzerland & -0.15 & 0.21 \\
Norway & -0.21 & -0.34 \\
Poland & 0.48 & n.a. \\
Slovak Republic & -0.09 & n.a. \\
Canada & 0.30 & 0.05 \\
Czech Republic & -0.11 & n.a. \\
New Zealand & -0.03 & 0.10 \\
South Korea & 0.34 & 0.31 \\
Iceland & 0.23 & 0.25 \\
Spain & 0.47 & 0.32 \\
\hline
\end{tabular}

Source: Authors' calculations and Brinca et at. (2016). Note: Data are annual averages for quarterly indices $(2008 \mathrm{Q} 1=100)$. All data series were detrended by taking first differences. Authors' data series are for 1960-2015 and the data series from Brinca et al. (2016) are for 1981-2015. 


\section{SFB 649 Discussion Paper Series 2017}

For a complete list of Discussion Papers published by the SFB 649, please visit http://sfb649. wiwi.hu-berlin.de.

001 "Fake Alpha" by Marcel Müller, Tobias Rosenberger and Marliese UhrigHomburg, January 2017.

002 "Estimating location values of agricultural land" by Georg Helbing, Zhiwei Shen, Martin Odening and Matthias Ritter, J anuary 2017.

003 "FRM: a Financial Risk Meter based on penalizing tail events occurrence" by Lining Yu, Wolfgang Karl Härdle, Lukas Borke and Thijs Benschop, January 2017.

004 "Tail event driven networks of SIFIs" by Cathy Yi-Hsuan Chen, Wolfgang Karl Härdle and Yarema Okhrin, January 2017.

005 "Dynamic Valuation of Weather Derivatives under Default Risk" by Wolfgang Karl Härdle and Maria Osipenko, February 2017.

006 "RiskAnalytics: an R package for real time processing of Nasdaq and Yahoo finance data and parallelized quantile lasso regression methods" by Lukas Borke, February 2017.

007 "Testing Missing at Random using Instrumental Variables" by Christoph Breunig, February 2017.

008 "GitHub API based QuantNet Mining infrastructure in R" by Lukas Borke and Wolfgang K. Härdle, February 2017.

009 "The Economics of German Unification after Twenty-five Years: Lessons for Korea" by Michael C. Burda and Mark Weder, April 2017.

010 "DATA SCIENCE \& DIGITAL SOCIETY" by Cathy Yi-Hsuan Chen and Wolfgang Karl Härdle, May 2017.

011 "The impact of news on US household inflation expectations" by ShihKang Chao, Wolfgang Karl Härdle, Jeffrey Sheen, Stefan Trück and Ben Zhe Wang, May 2017.

012 "Industry Interdependency Dynamics in a Network Context" by Ya Qian, Wolfgang Karl Härdle and Cathy Yi-Hsuan Chen, May 2017.

013 "Adaptive weights clustering of research papers" by Larisa Adamyan, Kirill Efimov, Cathy Yi-Hsuan Chen, Wolfgang K. Härdle, July 2017.

014 "Investing with cryptocurrencies - A liquidity constrained investment approach" by Simon Trimborn, Mingyang Li and Wolfgang Karl Härdle, July 2017.

015 "(Un)expected Monetary Policy Shocks and Term Premia" by Martin Kliem and Alexander Meyer-Gohde, July 2017.

016 " Conditional moment restrictions and the role of density information in estimated structural models" by Andreas Tryphonides, July 2017.

017 "Generalized Entropy and Model Uncertainty" by Alexander Meyer-Gohde, August 2017.

018 "Social Security Contributions and the Business Cycle" by Anna Almosova, Michael C. Burda and Simon Voigts, August 2017. 